\title{
TRADITIONAL COSMOLOGY AND NATURE CONSERVATION AT THE BOMFOBIRI WILDLIFE SANCTUARY OF GHANA
}

\author{
Dickson Adom \\ Kwame Nkrumah University of Science and Technology, Ghana \\ e-mail:adomdick@yahoo.com
}

Received: 14.08.2017

\begin{abstract}
Cosmological belief systems play significant roles in the conservation of the biodiversity of the residents in the Kumawu Traditional Area of Ghana. It is regrettable to realise that they have been unjustly labeled as an obstacle to scientific progression, resulting in their low voice in the nature conservation initiatives in the area. Thus, the research was aimed at unearthing the conservation ethos of the cosmological belief systems, while justifying with substantial facts, why they must be utilised in modern conservation initiatives. A phenomenological study using Focus Group Discussions, personal interviews and direct observations assisted in the gathering of qualitative data which was rigorously analysed via data analysis spiral approach. The findings revealed that cosmological belief systems greatly influence the attitudes of the residents in the Kumawu Traditional Area toward the natural resource conservation in the Bomfobiri Wildlife Sanctuary. The study contends that nature conservation planners in Ghana must look in-depth into the cosmological belief systems in the area and tag them as a potential traditional biodiversity strategy and as a complement to the conventional scientific models to halt the menace of biodiversity depletion in the Bomfobiri Wildlife Sanctuary.
\end{abstract}

Key words: behavioural attitudes, biodiversity, Bomfobiri Wildlife Sanctuary, conservation, cosmological belief systems, Kumawu Traditional Area, nature

\section{Introduction}

Since time immemorial, humans hold the idea that the cosmos or universe is beyond the physical dimensions. Thus, traditional African societies firmly hold on to the ideology that a host of spirits live amongst humans, consistently shaping their worldviews. The worldview of people determines their beliefs and their eventual behavioural attitudes (Chalk, 2006). Thus, the strong belief that the cosmos is full of spiritual beings impacts greatly on the attitudes and obligations of many people towards the environment. This inhabitation of the cosmos by spirits has much weight among traditional African societies and has been the source of nature conservation (Kehinde, 2013). Owing to the reverential fear, awe, and respect they have towards the spiritual dimensions of nature, the indigenous communities in Ghana strives very hard to care and sustain nature's resources (Adom et al., 2016). Grim (2001) concurs that even in the era of globalisation and westernisation, the belief that nature and its resources are abodes of spirits still exert significant influence among Africans. The cosmological belief systems, including the belief in a Supreme Deity (God), ancestors, spirits, animism, sorcery, and witchcraft highly impacts on the attitudes of many Ghanaians regarding nature. Taringa (2006) indicates that the African indigenous societies particularly among the Shona people of Zimbabwe believe that the wanton depletion and/ or abuse of the biodiversity resources in nature would anger the higher spirits, restrain and regulate their behavioural attitudes toward unfriendly environmental practices. The reason for this belief is the same as that of the Aboriginal people who hold the traditional cosmology that all animate objects have life spirits in them and as such can be talked to (Aikenhead \& Masakata, 2007). Owing to this belief of an inhabitant spirit in the things in nature, Adom (2016a) noted that it is very rare to see a typical member of the Asante kingdom in Ghana wantonly destroying the resources in nature. This is due to the strong prevailing influence of their traditional cosmological belief systems. The Asantes and the majority of Ghanaians believe that if they engage in environmentally friendly activities toward the resources in the environment, they would be at peace with the spirit beings in the cosmos. Rim-Rukeh et al. (2013) elucidate from the perspective of Nigeria, that this peaceful relationship with the spirit forces, is believed to protect the people from any form of harm such as drought, sicknesses, barrenness, famine and even wars. On the other hand, being inhumane toward the environmental resources would rather spell doom for the people. The belief among the majority of the 
ethnic cultures such as Kumawu in the Ashanti Region of Ghana is that the angered spirits would vent their wrath on them in the form of untimely and disgraceful death, strange illness, impotence and the like if nature's resources are abused (Boamah, 2015). This clearly shows that living in harmony with nature has constantly been perpetuated by the stringent traditional cosmological belief systems held by many ethnic societies in Ghana. The same traditional cosmology is being implemented in Brazil for the conservation and sustainable use of biodiversity. The Ministry of Culture in Brazil has spearheaded support programmes and funding for the application of traditional cosmology in nature preservation (NBSAP, 2015). Japan has established a sui generis system to assist in the preservation of the traditional cosmology evident in the cultural practices of the people (Adom, 2016b).

Despite the importance of traditional cosmology in nature conservation, there is the threat of them being weakened or even eroded entirely. This is attributed to the widespread westernisation and its instruments of education and religion. Museka \& Madondo (2012) affirm that the Western informed traditions are gradually replacing the environmental stewardship and accountability of indigenous Africans that is characterised by humane and sustainable community environment relations. The impact of Western religion and education on some scholars and conservationists has blurred their outlook of these traditional cosmological belief systems held by the indigenous communities in Ghana. As Wilder et al. (2016), as well as Gbolonyo (2009), revealed, some scholars and conservationists label these traditional cosmological belief systems as satanic, primitive, anti-science and even setbacks to societal progression because they dwell on spiritual variables. Some conservation planners feel that the cosmological belief systems rest in the past and are superstitious, thus, are incapable of providing anything valuable as far as nature conservation in the modern society is concerned (Battiste, 2002). This wrong perception is shadowing the great import of conservation ethos evident in these traditional cosmological belief systems in the full glare of nature conservation planners in Ghana. As a result, many of these conservationists through their programs and activities in these local regions ignore the demands of the traditional cosmological belief systems. This attitude has resulted in the gross and inhumane resource exploitation and degrading environmental practices with no sympathy or whatsoever towards nature. It is no wonder that
Ghana is paying greatly for the wanton depletion of nature's resources through the abolishment of the traditional cosmological belief systems held by the diverse local communities where Protected Areas (PA) have been established. The constant reduction, extinction and/or endangering of native species, as well as the harsh and escalating numbers of environmental disasters like flooding, bush fires, and droughts that are destroying many PA systems in Ghana are products of this stubborn negligence in realising the conservation potentials of the traditional cosmological belief systems of Ghanaians.

We need to realise that the impact from the Western cultural tradition does not in any way imply that Ghanaians, in general, have entirely left hold of their indigenous cosmological belief systems. Awuah-Nyamekye (2013) argues that many Ghanaians still hold on to these traditional cosmological beliefs and as such, they have great potentials for advancing the course of nature conservation. In fact, the remaining tracts of forests, many of which have been transformed into PA systems in Ghana that are still intact are as a result of the resiliency of the traditional cosmological belief systems in positively monitoring the behaviour of many Ghanaians towards nature and its resources (Iyoro \& Ogungbo 2013). Soini \& Dessein (2016) are convinced that the traditional cosmological belief systems of indigenous cultures, even in the modern age, possess behavioural corrective elements that can change the outlook of people towards the biodiversity in nature.

Interestingly, G'Nece's (2012) study even dissuades the wrong assertion made by some conservationists that the traditional cosmological belief systems are retrogressive in development and are anti-science. His study indicates that the traditional cosmological belief systems as part of indigenous knowledge systems have been proven as scientifically accurate and reliable. Awuah-Nyamekye (2013) corroborates that the Ghanaian traditional cosmological belief systems have scientific underpinnings that are comparable and resonates very well with the scientific models of conservation. Arguably, it is true that not every cosmological belief system may be correct when measured by modern scientific standards. However, Abrams \& Primack (2001) unequivocally stressed that they were valid when gauged by their own standards and they have the power to regulate people's code of behaviour positively. Ens et al. (2016) hinted that directives have been given to conservation planners to include the indigenous knowledge systems of which 
traditional cosmological beliefs form a greater part in international and national policy programs and policies. Thus, Wilder et al. (2016) recommend that developers of conservation initiatives must critically consider the great conservation potentials of traditional cosmological belief systems in nature conservation and sustainability. There is the need to justify the great conservation potentials of the traditional cosmological belief systems to the conservation developers and highlight the significant roles they play in nature conservation. Using the example of the Kumawu Traditional Area in the Ashanti region of Ghana, the researcher discusses the astronomical worth of traditional cosmological belief systems in nature conservation. The study seeks to furnish answers to the following research questions: What are the traditional cosmological belief systems held by the local people living around the Bomfobiri Wildlife Sanctuary in Kumawu? What are the philosophical, scientific and conservation ethos of these traditional cosmological belief systems held by the local people living around the Bomfobiri Wildlife Sanctuary in Kumawu? How can conservation planners incorporate the values inherent in the traditional cosmological belief systems as a complement to the scientific conservation practices for the management of the rich biodiversity resources in the Bomfobiri Wildlife Sanctuary? These questions need to be essentially answered because the traditional cosmological belief systems are seen as powerful agents that can complement the less sustainable policies for nature's conservation while offering a creative process for new policy development (Hedlund-de Witt, 2013). There is an academic vacuum in the researches on nature conservation that pinpoints the potentials of traditional cosmological belief systems held by the local people living in the fringe communities surrounding the Protected Areas in Ghana. The purpose of this paper, then, is to provide an empirical and theoretical insight into the contributions of traditional cosmological belief systems and its immense relevance in Ghana's fight for a more conservative and sustainable way of managing her natural resources using the case of the Bomfobiri Wildlife Sanctuary in the Kumawu Traditional Area in the Ashanti Region of Ghana.

\section{The Concept of Cosmos}

Hedlund-de Witt (2013) traces the word Kosmos to Greek origin. Its English word equivalent is «Cosmos» which means the «universe». The word refers to the beauty and order that the Greeks believed existed between the universe and its human subjects pivoted on the universal moral laws. These universal moral laws governed all the life in the universe, including the animate and inanimate bringing order to the disorganised things in the cosmos. A stringent observation of all the life in the cosmos, especially humans in relation to nature and its resources as well as the numerous spiritual beings bring about the harmony, beauty, and order expected to exist in the universe. Taringa (2006) explains that the cosmos to the African comprises of the tangible and intangible worlds. The tangible world includes animals, plants, and all biological life as well as objects without biological life, all of which are imbued with the powers of the Supreme Deity, ancestral spirits connected spiritually. On the other hand, the intangible or unseen world is inhabited by spiritual beings with the Supreme Deity being their leader. The elders who sit in the seat of the ancestors are to ensure that society members abide by the accepted moral laws or cosmic order given by the Supreme Deity (Adom, 2014).

\section{The Concept of Cosmology}

Abrams \& Primack (2001) describe cosmology as the «picture of the universe (cosmos) a culture agrees on.» Behind this splendid scenery of the cosmos is the unique story of the sacred link the world described in the context of the people and humans as well as their moral responsibility towards it. This story accompaniment might have been because of the ancient association of the term cosmology with cosmogony which means «story» (Bowie, 2006). The term holds varying understanding in science and anthropology. The sciences define cosmology as «the science or study of the origins and evolution of the universe» while in Anthropology it is said to be «the set of knowledge, beliefs, interpretations and practices of a society or culture related to explanations of the past, present and future of the universe as well as the role and meaning of humans, life, and the world within the cosmos» (Cosmology Blog, 2008). In a simple explanation, social anthropologists refer to it as «the system of beliefs and practices of a people» (Leach, 1982). The cosmologies of indigenous and traditional societies often command respect for nature, demanding for a peaceful and balanced co-existence between the parts of the universe (people, ecosystems, and the biosphere) which are composed of matter, energy and spirit (Reichel, 2005).

The cosmology of people gives them a sense of belonging, meaning, and purpose, exerting a powerful influence on the behaviour and choices of mem- 
bers of the society (Kehinde, 2013). This means that if a society's cosmology resonates very well with environmental stewardship and conservation, its members are likely to engage in environmentally friendly activities. From the cosmological perspective of an indigenous African, the abuse and exploitation of biodiversity for satisfying the present needs of man is unjust, immoral and unethical (Museka \& Madondo 2012). Infield \& Mugisha (2013) explain that the cosmologies of most communities in Ghana and Africa as a whole require that society members use the biodiversity resources in great moderation with the future generation in mind. The traditional Kumawu cosmology is part of the cosmologies that advance the understanding of nature and the cosmos. Reichel (2005) believes that such cosmologies have the power of sensitising people to be conscious of caring for the environment while ensuring the social-environmental well-being of global communities. If such is the case, then the noticeable marginalisation of the Ghanaian cosmological beliefs which has resulted from colonialism, scientific and technological development, Christianity and cultural prejudice (Museka \& Madondo, 2012) must be looked at critically. Great intensification of cultural education on the traditional cosmology of Ghana must be carried out, especially in the various educational institutions if sustainable utilisation of biodiversity is to be achieved (Grenier, 1998).

\section{The Concept of Worldview}

The term «worldview» (Weltanschauung in German) was coined by a German philosopher in the late half of the eighteenth century to explain the powerful influence of perception on the human mind (Hedlund-de Witt, 2013). In a general view, worldview refers to how the individual or society views the world. The American scientific Affiliation defines worldview as the theory of the world, used for living in the world. This theory of the world is a network of ideas and attitudes of the world, humans, and life as well as a comprehensive system of beliefs about people. It underscores the great impact that the ideas, values, beliefs and perceptions of individuals and the society can have on our choices in life. Schlitz et al. (2010) concur that worldview dictates the way people view the world, influencing their behaviour in relationship to society and the world around them. It is a collection of values and beliefs about life and the universe that is common to a group of people (Our Worldviews, 2016). It is true that society collectively may hold a worldview that is common and shared among society members.
However, an individual can have a personal worldview aside from the generally ones accepted by a society (Schlitz et al., 2010). Various factors influence and shape the worldview of an individual or society. The geographical location, ideas, and knowledge, social relations, culture, religion, genetic tendencies and experiences are powerful agents that can change a person or society's worldview (Our Worldviews, 2016; Schlitz et al. 2010). It is the way people use their values in responding to issues such as environmental ones (Reuter, 2013). For instance, Gamble (2016) avers that if one's worldview makes them feel connected to all the things in life, they will be more inclined to conserve and care for the planet and its resources. Therefore, a deep understanding of worldviews has a pivotal role to play in remedying the highly complex global environmental degradation challenges (Hedlund-de Witt, 2013). Indeed, the worldview of a group shapes their beliefs and perceptions which impact on the behaviour they exhibit. Conservation planners must thus seek to comprehend the perceptions, ideas, and beliefs that collectively make up their worldview in policy development governing the sustainable use and conservation of biodiversity. Pretty et al. (2009) posit that the worldviews of various pre-industrialised societies have contributed to the development of traditional practices that «sustainably manage ecological integrity» (p. 4). This traditional worldview carries moral capital, projecting the values of conservation and living with nature (Kehinde, 2013). Gamble (2016) as cited in Kehinde (2013) mentions that a worldview that one holds can change. This transformation is sometimes subtle for some worldviews while others are more obvious. Other worldviews are rigid and can resist any form of influence such as Westernisation, globalisation, Western education and others (Schlitz et al., 2010). The Ghanaian indigenous worldview which is geared towards religious beliefs has shown itself as rigid to the impact of its major external factor, Westernisation (Boateng, 1998). Shaped around local laws and precepts, Rim-Rukeh et al. (2013) contend that they have been strong enough to resist any negative impact from other worldviews. They remain intact and continue to influence the behaviour of the majority of Ghanaians toward environmentally sustainable practices (Boamah, 2015).

Some of the external factors that transform worldviews are degrading and if not curtailed would be destructive, affecting the societal members negatively towards their attitudes to the biodiversity resources in the environment. Museka \& Madondo 
(2012) cited the Western «atomised» cosmology that regards the human and non-human constituents of the universe as separate and independent as a negative impact on traditional worldview. This Western worldview promotes materialistic, exploitative spirit that is short-sighted and inclined towards present economic gains with no sustainability intent for the future generations (Boamah, 2015). Despite the firm worldview of the Ghanaians handed down for generations, it has been able to lay its negative net on the behavioural attitudes of some Ghanaians. These individuals need a change in their new Western-influenced lifestyle to the traditional Ghanaian worldview if a more sustainable Ghanaian society is to be built (Gifford et al., 2011). Generally, worldview or how an individual or society views the world, especially the biodiversity resources differ greatly. Van Asselt \& Rothmans (1996) categorise these views into four categories. They are the Hierarchist, Individualist, Fatalist, and Egalitarian viewpoints. The Hierarchists, Fatalists and Individualists hold a selfish and exploitative view of the earth and its resources, viewing all its risks as acceptable. They are not so much concerned about the sustainability and conservation of the biodiversity resources in nature. The earth and its resources to them are robust and as such thinks that it is capable of adapting to the continual abuse and overuse it faces. Far from the greedy and heartless treatment of the earth, the Egalitarians view nature as a fragile complex ecosystem, parallelling it to humans and as such must co-exist with them. As such, they abhor any inhumane activity that would affect the well-being of nature, viewing all forms of risks as unacceptable and morally unjust. Such is the worldview of Ghanaians handed down to them by their forebears. Kehinde (2013) still feels the deep respect that some African countries have towards the environment and its resources. Their worldview is anthropocentric, thus, seeing everything as related to human beings and must, therefore, be treated with the utmost care (Taringa, 2006). Rim-Rukeh et al. (2013) and the International Institute for Environment and Development (Uphoff, 1992) add that the cultural practices of the Ghanaians and their other African counterparts are environmentally friendly and sustainable. All life is held sacrosanct with the well-being of the earth seen as essential for human survival.

The worldview of every individual or society answers six vital questions about the world. These questions are similar to those undertaken by philosophers in their search for truth. It is not misplaced because a worldview is seen as the «highest manifestation of philosophy» (Vidal, 2008). Table 1 below shows how the questions are answered based on the unadulterated traditional worldview of Ghanaians. The worldview is more religious and thus based on strong cosmological belief systems.

\section{Traditional Cosmological Belief Systems and Nature Conservation}

The traditional cosmological belief systems of the Ghanaians include their belief in the Supreme Deity, belief in the ancestors, belief in spirits/divinities, belief in animism and belief in sorcery and witchcraft.

Belief in the Supreme Deity (God) and Nature Conservation. The belief in a Supreme Deity is ancient to the people of Kumawu right from the indigenous times. He is said to be the creator of all the things, hence the title Oboade (Creator of things). Taringa (2006) indicates that the Supreme Deity or God is believed among Africans that $\mathrm{He}$ is the first and great ancestor. His power is unmatched and as such, He comfortably occupies the topmost position in the hierarchy of spirits that are believed to exist in the cosmos. This is reflected in the titles that the various ethnic societies in Ghana address Him with. For instance, He is called Onyankopon (Onyame- god, Ko- Only, Pon- Great). He is distinct from the other gods that the Kumawu people worship. It indicates that $\mathrm{He}$ is the greatest amongst all gods and spirits believed to reside in the cosmos. This resonates with what Amponsah (1977) in his classic work said of Him that «He cannot be placed in the rank and file of the lesser gods» ( $p$. 14). As Awuah-Nyamekye (2013) highlighted, the Supreme Deity always requires that His creatures honour and care for the things that He has created. Any form of abuse unbridled usage and wanton destruction of plants, animals, river bodies and the other precious things in nature would register His full displeasure and wrath. Boamah (2015) contends that the reverential fear and respect for the Supreme Deity holds Ghanaians back, especially when they are about to undertake any foul act. This is expressed in the common saying of the Kumawu people «Onyame nti» (Because of God). Thus, because of the fear of displeasing the Supreme Deity which would bring bad luck and curses, the resident of Kumawu would want to exhibit good moral behaviour especially towards the things in nature. Therefore, to earn His untold blessings and feel the «finger» of the Supreme Deity in the life of an individual requires that he gently and sustainable use the biodiversity resources in nature. 
Table 1. Kumawu Traditional Worldview

\begin{tabular}{|c|c|c|}
\hline $\begin{array}{c}\text { Philosophical } \\
\text { Discipline }\end{array}$ & Questions & Ghanaian Traditional Worldview \\
\hline $\begin{array}{l}\text { Ontology } \\
\text { (Model of reality as } \\
\text { a whole) }\end{array}$ & $\begin{array}{l}\text { What is? } \\
\text { 1. The nature of the world? } \\
\text { 2. How is it structured and how does it } \\
\text { work? } \\
\text { 3. Why is there something rather than } \\
\text { nothing? }\end{array}$ & $\begin{array}{l}\text { 1. The world is in dualistic form, thus, the spiritual world } \\
\text { and the physical world. } \\
\text { 2. The world is densely populated with spirits who fight } \\
\text { against each other and influences the activities of man. } \\
\text { 3. These spirits are arranged in a hierarchical order based } \\
\text { on the extent of their powers. The Supreme Deity tops } \\
\text { the hierarchy followed by ancestors, divinities, and lesser } \\
\text { spirits of things in nature, sorcerers, and witches. } \\
\text { All things exist because the Supreme Being (Oboadee- } \\
\text { Creator) created them to co-exist in harmony and peace. } \\
\text { Humans must view everything in nature as sacrosanct and } \\
\text { maintain equilibrium, order, and peace amongst the spirits } \\
\text { residing in the dualistic world or cosmos. }\end{array}$ \\
\hline $\begin{array}{l}\text { Explanation } \\
\text { (Model of the past) }\end{array}$ & Where does it all come from? & $\begin{array}{l}\text { The ancestors handed down the precepts and rules (eth- } \\
\text { ical code of living in harmony with nature) to the pres- } \\
\text { ent generation. } \\
\text { This is embedded in cultural practices like festivals, } \\
\text { myths, folklores, proverbs, songs, cosmological beliefs, } \\
\text { taboos, totems and other traditional institutions. } \\
\text { The elders in the society pass on the ethical code of living } \\
\text { or expected moral behaviour to the young ones informally } \\
\text { through the traditional institutions in their pristine form as } \\
\text { handed down to them by the ancestors. }\end{array}$ \\
\hline $\begin{array}{l}\text { Prediction } \\
\text { (Model of the future) }\end{array}$ & $\begin{array}{l}\text { Where are we going? } \\
\text { 1. What will be the fate of life in universe? } \\
\text { 2. Which alternative should we promote } \\
\text { or avoid to give us possible futures? }\end{array}$ & $\begin{array}{l}\text { 1. There is life after death after the physical passing of } \\
\text { man from the physical world to the spiritual world. } \\
\text { 2. A good moral life would attract good favours and a } \\
\text { peaceful dwelling place with the Supreme Deity, ances- } \\
\text { tors, and spirits. It qualifies one to be the rank and file of } \\
\text { the ancestors. A bad moral life would attract the displea- } \\
\text { sure of the Supreme Deity, ancestors, and spirits leading to } \\
\text { eternal destruction full of pain and anguish. }\end{array}$ \\
\hline $\begin{array}{l}\text { Axiology } \\
\text { (Theory of values) }\end{array}$ & $\begin{array}{l}\text { What is good and what is evil? } \\
\text { 1. What should we strive for? } \\
\text { 2. How do we evaluate global reality? } \\
\text { 3. What is the meaning of life? }\end{array}$ & $\begin{array}{l}\text { 1. The norms, values, and precepts as told by the elders in } \\
\text { communities are used as a yardstick in evaluating what is } \\
\text { good or evil. } \\
\text { 2. We should strive for living in unison with the accepted } \\
\text { ethical and moral code in the Ghanaian community. } \\
\text { This includes avoiding any inhumane treatment of nature } \\
\text { and its resources while striving very hard to conserve and } \\
\text { sustain nature for future progeny. } \\
\text { 3. A well led and fulfilled life hinges on the satisfaction of } \\
\text { living in line with the accepted ethical and moral code in } \\
\text { the Ghanaian society. }\end{array}$ \\
\hline $\begin{array}{l}\text { Praxeology } \\
\text { (Theory of actions) }\end{array}$ & \begin{tabular}{|l} 
How should we act? \\
What are the general principles according \\
to which we should organise our actions?
\end{tabular} & $\begin{array}{l}\text { The elders are to be respected and the code of ethics they } \\
\text { instruct must be observed meticulously. Taboos, totems } \\
\text { and other traditional institutions and cultural practices } \\
\text { must be honoured. Nature and its resources are sacred } \\
\text { and must be revered and cared for. The use of nature's } \\
\text { resources greedily with no plans of conservation and sus- } \\
\text { tainability would attract the wrath and possible misfortune } \\
\text { from the Supreme Being and ancestors. }\end{array}$ \\
\hline $\begin{array}{l}\text { Epistemology } \\
\text { (Theory of knowl- } \\
\text { edge) }\end{array}$ & $\begin{array}{l}\text { What is true and what is false? } \\
\text { How can we acquire knowledge? }\end{array}$ & $\begin{array}{l}\text { The knowledge of what is true and false depends on the } \\
\text { accepted ethical code of behaviour in the Ghanaian society. } \\
\text { This knowledge is acquired informally through initiation } \\
\text { rites and from the elders in the community. }\end{array}$ \\
\hline
\end{tabular}

Source: Structure of the table was adapted from Vidal (2008) 
Also, the people believe that the Supreme Deity is the «Great Judge» (Gyekye, 1996). This means that individually, they would account to Him the way they led their lives here on earth. This account of one's led life course includes how he/ she treated the things in nature since Ghanaians believe that they are stewards of the things in nature (Golo \& Yaro, 2013). This account is given after one's physical passing or death. A good account, void of any abuse or wanton depletion of nature's resources would mean a qualification as an ancestor and a good dwelling place with the Supreme Deity (Opoku, 1978). On the other hand, a bad account cluttered with any traces of selfish usage or abuse of the bio-resources in nature would mean a total destruction of an individual with no hope of spiritual life enjoyed in exuberance with the ancestors and the Supreme Deity. Therefore, the belief in the Supreme Deity regulates the behaviour of the Kumawu residents towards nature and its resources. Thus, Boamah (2015) and Rim-Rukeh et al. (2013) argue that this belief has ecological ramifications for the sustainability and conservation of biodiversity. As such, these researchers believe that the belief can be a potential strategy in nature conservation initiatives in Ghana and as such must be looked at by conservation planners.

Belief in Ancestors and Nature Conservation. Residents of Kumawu believe that the good deeds of an individual while on earth are handsomely rewarded by the Supreme Deity. This is reflected in the belief regarding the ancestors. An ancestor is someone who led a good moral life that is exemplary while on earth and has been rewarded by the Supreme Deity with spiritual life. All ancestors are believed to be residing in the spiritual world (Adom, 2014). Owing to this, the ancestors who are said to be «living shades» or «living dead» (nananom nsamanfo- spirited elders), constantly police the activities of man on earth (Gyekye, 1996). As policing agents of the lives of man, they are active in bestowing blessings or calamity which is dependent on how one leads his/her life (Taringa, 2006). Ghanaians highly revere the ancestors because they were their elders and predecessors who live close to the Supreme Deity because of their virtuous lives (Amponsah, 1977). This belief in ancestors is so strong in Ghana such that some households desist from sweeping at nights because it is believed the ancestors who have visited would be dirty (Opoku, 1978). Adom (2014) corroborates that some Ghanaian ethnic societies who uses the traditional source of fire from firewood desist from putting out the fire at night. The belief is that the ancestors will use it at night to reheat the food that was left for them.

As advocates of environmental sustainability and the owners of the land, the ancestors reward anyone who treads their footsteps and punishes severely, all those who abuse nature's resources (Awuah-Nyamekye, 2013; Adom, 2016a). Msuya \& Kideghesho (2009) contend that the people in the East Usambara, Mungi and Mazimbo districts of Tanzania also desist from resource exploitation because of the strong believe in ancestors. There are certain taboos that the ancestors require that they are observed in the usage of the biodiversity resources in the environment. For instance, the felling of trees within 30 meters radius from streams or rivers is highly detested by the ancestors (Rim-Rukeh et al., 2013). The Zimbabweans are not supposed to cut down all large trees because they have been assigned to the ancestors (Taringa, 2006). There are instantaneous punishments believed to issue from the ancestors for defaulters of unfriendly environmental practices. These include epidemics, drought, and infertility amongst others (Shastri et al., 2002; Boamah, 2015). In some societies, reduction of proceeds in economic activities is attributed to the ancestors when the society is not living in consonance with the stringent laws and regulations of the ancestors. For instance, Adom et al. (2016) noted this among the residents of Abono in the Ashanti region of Ghana where the Bosomtwe Lake is located. The elders in the community lamented that the smaller sizes of fishes caught as well as the massive reduction in the quantities of catches were misfortunes brought on them by the ancestors because most of the young residents were living contrary to the dictates of the ancestors. This shows the high impact of the belief amongst Ghanaians. The same belief in traditional cosmology is also high in China where the belief in the existence of ancestors as spiritual overseers of all forms of environmental activities exist (Bergmann \& Gerten, 2010). Justifiably, some scientists criticise the punishments that are believed to issue from the ancestors as unscientific and irrational. However, Boamah (2015) insists that it has positive implications because of its ability in regulating the attitudes of Ghanaians towards nature conservation. Even in the face of westernisation, the majority of Ghanaians still holds on to the belief in ancestors and their great impacts on their lives. Others who are trapped in the grips of Christianity may not believe in the punishments issuing from 
the ancestors, yet, they respect them based on their immense contributions to the development of modern societies. This underscores the strong assertion of the researcher that the cosmological belief system holds strings on the behavioural administration of Ghanaians and as such it could be a potential conservation strategy for biodiversity.

Belief in Divinities / Spirits and Nature Conservation. The divinities or spirits are believed to be messengers of the Supreme Deity. They are assigned to perform special functions as representatives of Him. They act as intermediates between the Supreme Being and men (Amponsah, 1977). As emissaries of God, they act and do His will. Some exercises authority over things in nature such as trees, river bodies, rocks, animals and the like (Taringa, 2006). The natural objects serve as their abodes or habitats. This debunks the idea of some western scholars who thought that the Ghanaian forebears were idol worshippers and thus, did an act of obeisance to lifeless objects in nature. Others supervise activities such as hunting, fishing, war, fertility etc. (Adom, 2014). Asase Yaa among the Akans of Ghana believes that she is the earth deity in charge of the fertility of the earth and humans. She is the custodian of morality and social decorum due to her abhorrence of bad environmental activities (Boamah, 2015). The River Tano among the Akans is regarded as the river god (Bosompo) and the god of thunder (Opoku, 1978). The Akans of Ghana refer to all divinities as Abosom (Abo-stone, Som-worship) probably to liken their immense strength to the resiliency of stones. Adom (2014) mentions that the Supreme Deity has given the divinities the special powers to carry out their main duty of protecting communities. Therefore, when there is a catastrophe in the society such as the outbreak of an epidemic, drought, and others, they are consulted through libation to petition them for their assistance (Amponsah, 1977). Society's progression largely depends on their help. Taringa (2006) noted that when a man does things in the will of the divinities, they could instruct society members with special skills in art, singing, healing, hunting and divining aside their core duty of community protection. In the case of the spread of an epidemic, the divinities can help a traditional priest to find the right «medicine» or cure for the ailment (Awuah-Nyamekye, 2013). This is usually revealed to the traditional priest in a dream or trance.

However, when the community members refuse to heed to the laid down restrictions and laws, they punish them with the same misfortunes that they protect the entire society from (Adom et al., 2016). Boamah (2015) mentions that the spirits among the Akans of Ghana detest the using of poisonous chemicals in fishing as well as defecating or farming near water bodies and rivers. Defaulters are punished with strange diseases, instant death or even drowning. These stringent sanctions serve as a restraining factor against the abuse or wanton depletion of nature's resources. Kehinde (2013) admits that because the divinities inhabit the resources in the environment, they are carefully handled with deep respect and awe. Thus, the belief in spirits in the cosmological belief systems can be a latent conservation strategy that can enhance the moral values of Ghanaians to monitor their relation to the natural environment (Museka \& Madondo, 2012).

Belief in Animism and Nature Conservation. Aside from the belief that Ghanaians have concerning things in nature inhabited by spirits, they again hold the belief that the things in nature also have spirits or souls independent of the divinity that inhabits them. Taringa (2006) concurs that some aspects of the natural world are believed to be charged with powers emanating from the Supreme Being. Diawuo \& Issifu (2015) strongly posit that due to their sacrilege and powers, they must not be abused in any way. Yet, their powers can be tapped by man through ritualistic performances to prevent certain mishaps in the society (Adom, 2016a). However, they are used in great moderation due to the fear of being invoked with a cure by the indwelling soul. Thus, aspects of the things in nature, such as the barks of trees, the furs of certain birds, the teeth of some animals are used for this ritualistic healing. Crocodiles, snakes, and birds are believed to possess fertility powers to rid of sterility in men and women. Thus, parts of these animals are used in preparing special medicine to be used by infertile people. Msuya \& Kideghesho (2009) suggested that the use of only some parts of the trees to prepare concoctions for healing as well as the usage of parts of animals aided the conservation and sustainable use of these resources in nature.

Moreover, the institution of totemism amongst the various ethnic affiliations in Ghana has greatly assisted in the conservation of the biodiversity resources of the environment. Adom (2016a) defines a totem as «a special animal, bird, plant or object which an ethnic society, family or clan revere as sacred because it might have provided a special assistance to that particular ethnic society or clan that ensured its survival» (p. 13). A totem is referred 
to as akyeneboa or atweneboa (atwene-lean boaanimal- An animal that is relied on for spiritual assistance in times of need) by the Akans of Ghana (Boamah, 2015). Thus, because of the tremendous contributions of the animal, it is shown reverence by members of the clan or ethnic affiliation. It is not to be killed and/or its meat or part is eaten or abused in any way because it is sacrosanct. Taringa (2006) contends that when a totemic animal is killed, the clan members are struck with strange ailments until a befitting burial is organised for the dead animal to appease its soul. When they find themselves within the vicinities and household of clan members, they are gently treated and even fed (Rim-Rukeh et al., 2013). The totemic animal or plant is, thus, always densely populated in the region of its affiliated ethnic society. This animistic view of things in nature promotes environmental awareness and sustainability (Museka \& Madondo, 2012). For instance, the rich species of the cashew tree in the Tsiame clan in Anlo, Volta region of Ghana is as a result of the totemic labelling of the plant (Amponsah, 1977). Their first ancestors who were about to perish as a result of hunger and thirst were rescued by the cashew tree who offered its nuts for them to feed on and water from a lake that some groups of birds directed them to drink. Thus, their leader instructed his fellow kinsmen, not to eat the nuts of the plant or use its wood for firewood. Adu-Gyamfi (2011) adds that monkey (colobus) is the totemic animal among the Brongs situated at Fiema in the Noranza North District in the Brong Ahafo region of Ghana, hence, their abundant numbers in the area. Likewise, the Traditional Lifestyles and Biodiversity use regional report (2003) mentioned that the local residents in the Ningo Prampram district of the Greater Accra region of Ghana revers turtle as a totem and thus, there is a high number of the turtle species in the locality. Boamah (2015) suggests that totemism or the belief in animism can be used as a vehicle for promoting solidarity in human societies especially Ghana for nature conservation.

Belief in Sorcery and Witchcraft and $\mathrm{Na}$ ture Conservation. Ghanaians believe that there are evil spirits called witches or sorcerers are bad members of the community who always cause pain and misfortune (Boamah, 2015). They operate in numerous ways, but their powers and influence on humans are limited. Any person shielded by the powers of the Supreme Deity, ancestors or divinities cannot be harmed or inflicted with any form of bad luck issuing from the witches or sorcerers.
However, the benefactor must have lived according to the virtues and laws of the higher spirits in the cosmos. Thus, Ghanaians are mandated to live in harmony with nature so as to enjoy such spiritual protection. Some artifacts like wristlets, anklets, and rings prepared with the images and parts of some plants and animals in the form of amulets and talisman are believed to ward off the attack of sorcerers and witches (Adom, 2014). Animals like dogs, cats, and eagles are said to have spiritual powers to combat the evil attack of witches. Their presence in the households of Ghanaian communities helps a lot in spiritual protection. Also, their skin, furs, or teeth are fashioned into protected gadgets by medicine men and traditional priests to be worn on the body for spiritual protection.

Moreover, some plant species like the basil, garlic, ginger, and palm in Ghana are believed to possess spiritual powers to ward off bad spirits (Cunningham, 1985; Yronwode, 2002). Also, the barks of the Nufutene (Kigelia africana (Lam.) Benth.) flora species is used in preparing concoctions for drinking and bathing to ward off any evil attack (Rattray, 1916). These species are deliberately planted in the compound of homes and farms to protect inhabitants from witches and sorcerers. At the entrances of homes of extended families in Ghana, the leaves of such plants placed in pots are hanged to drive away any influence of witchcraft and sorcery. Indirectly, the belief in witches and sorcerers by Ghanaians is ensuring the preservation and sustainability of some biodiversity resources and as such is a potential strategy for conservation. Also, the Asantes of Ghana believes of an evil spirit who is said to reside in thick forests called Sasabonsam (Sasa-Spirit, Bonsam-Evil). Opoku (1978) opines that Sasabonsam resides on top of economically viable trees such as Odum (Milicia excelsa (Welw.) C.C. Berg), Onyina (Ceiba pentandra (L.) Gaertn.), Betene (Elaeis guineensis Jacq.), Osese (Funtumia sp.) and others. He is often described in horrifying features like a monster. He is said to terrorise and kill stubborn people who enter the deepest caverns of the forest where they are not supposed to enter the sacred forests and groves. He is said to be in league with the witches in the society. Therefore, sacred forests that are not supposed to be entered as well as some species of trees that are not to be cut are strictly obliged by the residents of Kumawu. This reverential fear for the Sasabonsam spirit's vindictiveness on abusers of the biodiversity, especially the plant species have aided greatly in nature conservation in Ghana. 


\section{Material and Methods}

This research was based on an anthropological study at the Kumawu Traditional Area in the Ashanti Region of Ghana (Fig. 1). The study was carried out between January 2016 and May 2017 to investigate into the conservation ethos of the cosmological belief systems of the residents of Kumawu and how they could be mainstreamed into nature conservation initiatives in the Protected Area while serving as a model for other ethnic cultures in Ghana. Prior to this, the researcher and his research assistants carried out follow up activities to validate the initial findings in the preliminary research during the last quarter of 2015.

Two instrumental data collection instruments in the field of Anthropology thus direct observations and Interviews (Personal Interviews and Focus Group Discussion Interviews). These forms of interviews were appropriate because it aided the researcher in gaining detailed description and information (Fraenkel et al., 2012) about the cosmological belief systems held by the people and its impact on nature conservation. The direct observations were made with the aid of a well-designed observation checklist with the researcher acting as a non-participant observer. Sitting on the sidelines helped the researcher to document without distraction (Fraenkel et al., 2012), the significant roles that the cosmological beliefs of the people influenced their composure to the bio-resources in their environment. Also, it gave the researcher first- hand information (Kumekpor, 2002) on how the cosmological beliefs held by the people restrained them from engaging in unfriendly practices that would have degraded the biodiversity resources. Owing to the study falling within the qualitative research methodology, which usually does not involve a large number of respondents (Schiffman et al., 2008; Creswell, 2009), the sample size includes sixty (60) respondents from the following targeted groups and interviewed: Omanhene (Paramount Chief) of the Kumawu Traditional Area, Divisional Chiefs, Elders in the Traditional Council, Traditional Priests/Priestesses, Conservationists working in the Bomfobiri Wildlife Sanctuary and some residents. The percentage was obtained from the parameters set by Leedy \& Ormrod (2010) that in a qualitative research, for a population of less than five hundred (500), the researcher must select 50\%. Thus, $50 \%$ of the total population of one hundred and twenty (120) resulted in the sample size of sixty (60) used for the soliciting data for the study (Fig. 2; Table 2). The purposive sampling and random sampling selection procedures (Multi-sampling technique) of the above key informants was informed by the fact that they are stakeholders in the cosmological belief systems and environmental issues in the Kumawu Traditional Area (Nachmias \& Nachmias, 1992). A semi-structured interview guide was used during the interview and the average length of each interview session lasted for one and a half hour.

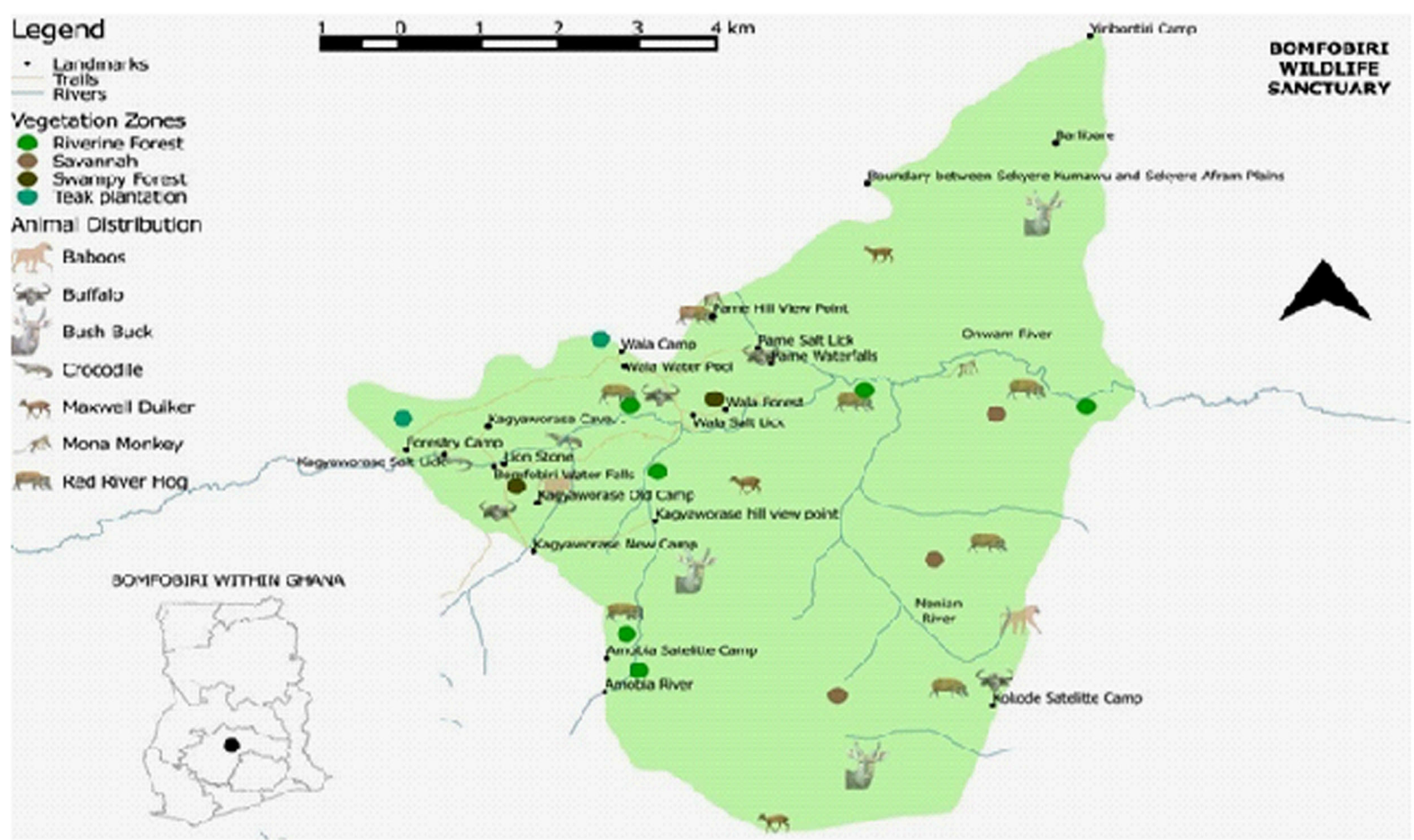

Fig. 1. Map of Kumawu showing the Bomfobiri Wildlife Sanctuary, Ashanti Region, Ghana. Source: From the Office Documents at the Bomfobiri Wildlife Sanctuary. 


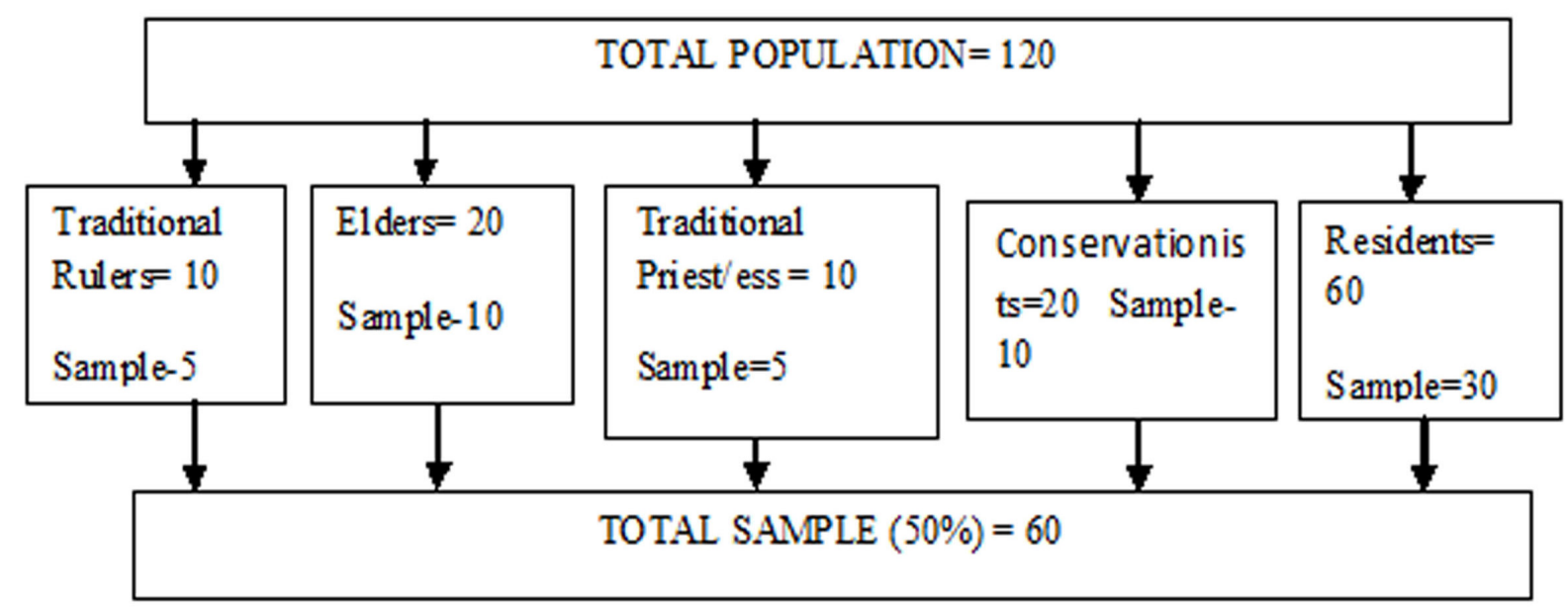

Fig. 2. Sampling Design for the study. Source: Author's Construct.

Table 2. Breakdown of Interviewees. Source: Author's Construct

\begin{tabular}{|c|l|c|l|}
\hline No. & Category of Interviewee & $\begin{array}{c}\text { Total No. } \\
\text { Selected }\end{array}$ & \multicolumn{1}{c|}{ Details } \\
\hline 1. & Traditional Rulers & 5 & $\begin{array}{l}\text { The paramount chief of Kumawu Traditional Area and four of his divi- } \\
\text { sional chiefs purposively selected from the traditional area. }\end{array}$ \\
\hline 2. & $\begin{array}{l}\text { Elders in the Traditional } \\
\text { Council }\end{array}$ & 10 & $\begin{array}{l}\text { The elders were randomly sampled from the 18 elders that formed the } \\
\text { traditional cabinet of Kumawu. }\end{array}$ \\
\hline 3. & Religious Officials & 5 & $\begin{array}{l}\text { Three traditional priests and two traditional priestesses were purposively } \\
\text { sampled from each of the 5 local communities in Kumawu. }\end{array}$ \\
\hline 4. & Conservationists & 10 & $\begin{array}{l}\text { The park manager of the Bomfobiri Wildife Sanctuary was purposively } \\
\text { selected while 9 conservationists were randomly selected. }\end{array}$ \\
\hline 5. & Residents & 30 & 30 residents in the Kumawu Traditional Area were randomly sampled \\
\hline
\end{tabular}

Source: Fieldwork, 2016 (Researcher's Construct)

Finally, the data analysis spiral was utilised for analysing the data obtained from the respondents (Creswell, 2009). The data were initially organised into specific facts in a logical order based on the order of questions directly transcribed from the interviews. Likewise, the direct observation of the impact of the traditional cosmological belief systems on nature conservation was systematically organised based on the items to be observed on the observation checklist. Large amounts of text transcribed were broken down into simple sentences and stories. Participants' voices were represented in the analysis with quotations to deepen the validity of the data (Pope et al., 2000). The entire data-set was then perused severally to get the sense of what it contains as a whole. Preliminary interpretations of the data organised were made. The emergent themes were generated and grouped accordingly. General patterns of the data were created and a final narrative analytical summary report was written. In addition, Smith \& Wishnie's (2000) organisation of information according to conservation purpose of rules applied in traditional practices and belief systems was used in highlighting the significance of the cosmological belief systems of the residents in Kumawu in nature conservation. The keys for the analysis include harvesting restraints, protection or propagation of resource species, regulating the onset or duration of harvests, avoidance of harmful habitat modification and patch-switching to maximise overall return.

\section{Theoretical Framework and Philosophical Underpinning for the Research}

The research was grounded in the interpretive philosophical paradigm. Myers (2008) opines that interpretive researchers hold the assertion that reality is socially constructed through shared meanings from respondents who have experienced the phenomenon. It was adopted because the researcher wanted to find out the philosophical meanings, values and the essence of the cosmological belief systems held by the residents in the Kumawu Township (Fig. 3). This aided him in understanding the original intent for the promulgation of the cosmological belief systems and its philosophical and scientific implications towards 
nature conservation. In addition, the research was undergirded by the culture theory by Milton (1996). The culture theory posits that environmental issues are best perceived and understood by deepening one's comprehension of the cultural traditions of local communities (Milton, 1996). The theory indicates that a study of the cosmological beliefs of a person can assist environmentalists to develop sustainable ways of developing the environment. This agrees with the worldview of the greater number of members of the Kumawu Traditional Area who believe that to maximise the sustainability of environmental development schemes, a consideration of their cosmological beliefs must be imperative.

\section{Study Area}

The Kumawu Township, where the study was conducted, is located in the Ashanti region of Ghana. It is under the Kumawu and Afram Plains District Assembly. Traditionally, the Kumawu Township is governed by the Kumawu Traditional council headed by the paramount chief of Kumawu, BarimaTweneboa Kodua V, who in private life is called Dr. Yaw Sarfo. He has a team of Odikro (sub-chiefs) such as the Kontihene, Gyaasehene, Akyeamehene, and Sanaahene that governs the numerous villages and communities and they account occasionally to the paramount chief. The Ghana Statistical Service population census in 2011 indicated that Kumawu has a total population of 37,832 , based on an estimated population growth of $2.6 \%$ per annum (Population and Housing Census, 2010). The majority of the residents are farmers by profession with relatively few residents serving as hunters. The Township has a gazette land assigned as a wildlife sanctuary known as the Bomfobiri wildlife sanctuary. It was established as a Protected Area in 1975. The sanctuary covers a total area of $53 \mathrm{~km}^{2}$ and is situated between $6^{\circ} 54^{\prime}$ to $6^{\circ} 61^{\prime} \mathrm{N}$ latitude and $1^{\circ} 07^{\prime}$ to $1^{\circ} 13^{\prime} \mathrm{W}$ longitude. The sanctuary has a semideciduous forest containing areas of more open Savannah with sandstone outcrops. The sanctuary has waterfalls with a varied biological diversity of flora and fauna and outstanding hills. The fauna recorded to be present in the sanctuary include species of mammals, Hornbills, Crocodiles, Birds, Green and Mona monkeys, Buffalo, Red River Hog, Duikers and Bush Bucks. The Bomfobiri Wildlife Sanctuary has been largely protected by a high impact of traditional cosmological belief systems like the belief in the Supreme Deity, ances- tors, spirits, animism, and sorcery and witchcraft. The huge impact of ancestral presence in the daily life of the people has instilled reverential fear and deep respect amongst residents to care and protect the biodiversity resources in the area. Moreover, the numerous taboos, totem, and other traditional institutions have helped the elders and the traditional council to uphold strict sanctions against any form of abuse to the biodiversity resources in the area. Unfortunately, because of a lack of the conservation agencies streamlining the traditional cosmological belief systems in their conservation initiatives to appeal to the consciences of the residents, there is currently resource abuse and gradual overstepping of the boundaries of the Bomfobiri Wildlife Sanctuary as well as high cases of illegal hunting and agricultural activities in the area.

\section{Results and Discussion \\ The Traditional Cosmological Belief Systems in the Kumawu Traditional Area}

The residents in the Kumawu town share all the cosmological belief systems as the researcher noticed from the responses from the participants in the study. However, the belief ratios in each of the cosmological belief systems differed greatly from the various factions of the population. For instance, the elderly members of the society expressed strong and close to equal belief in the Supreme Deity, ancestors, spirits, animism and sorcery, and witchcraft. In comparison with the younger members and conservationists in the enclave of the town, the belief in the ancestors, spirits, animism and sorcery and witchoraft in line with the conservation of biodiversity has waned greatly though the belief in God reigned high.

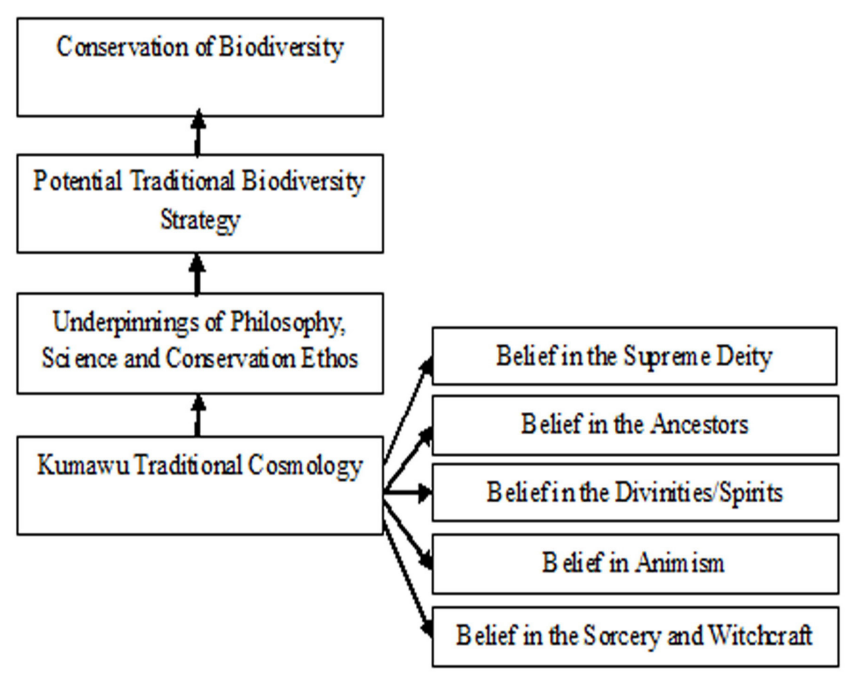

Fig. 3. Conceptual Framework for the study. Source: Author's Construct. 


\section{Belief in the Supreme Deity}

All the sixty (60) respondents interviewed demonstrated through their comments that they have strong belief in the Supreme Deity. The researcher did not notice any atheist among the respondents. They all agreed with the assertion that $\mathrm{He}$ is the creator and as such must be reckoned as such. Due to the reverential fear of God, it restrains many residents in Kumawu from engaging in foul acts towards the environment and its biodiversity resources. For instance, one of the elderly respondents told the researcher that "God hates wicked deeds such as the abuse and wanton destruction». Strong believers in the Supreme Being were passionate that the conservation and sustainable use of God's creation would trigger God's eternal blessings. This was evident in the comment of the parks manager. He said «Some of us have sacrificed our lives to conserve, preserve and sustain the resources God has created to earn his favour». The mere fact of displeasing the Supreme Deity and a retraction of His blessings impose reverential fear in the residents not to wantonly destroy the resources. Therefore, those who destroy and greedily use the resources in nature were referred to by some elderly respondents as «not fearing the Supreme Deity». The elderly respondents unequivocally told the researcher that "When God is angered, He holds back His rain, shows His anger in the form of droughts and sicknesses. Yet, when His orders, such as living in harmony with nature are honoured, He bestows His blessings and favours». These findings from the data correlate with the views of Boamah (2015) and Awuah-Nyamekye (2013) who opined that reverential fear for the Supreme Deity and His displeasure restrains many Ghanaians from engaging in any biodiversity malfeasance.

\section{Belief in Ancestors}

The respondents for the study shared the belief in ancestors, though the percentages differed based on the different factions of the sample interviewed. For instance, the statistical power realised amongst the elderly respondents soared up in comparison with the young respondents and conservationists. The majority of the elders in Kumawu feared greatly how their attitudes toward the biodiversity resources in the environment can determine their fate and approval of the ancestors. One of the sub-chiefs who is part of the traditional authorities said "I know that my ancestors in the spiritual realms are very much pleased with the way I have treated gently the environ- ment and its rich biodiversity resources and how I have jealously protected them even amongst stubborn residents. I am convinced that my ancestors would reward me soon with a good place when I join them after my physical passing». Therefore, as noted in the responses of the majority of the elders in the society, the state of their afterlife and the approval of the ancestors depended solidly on how they aided in ensuring the conservation and sustainable use of the biodiversity resources of the environment. This buttresses the observations made by the researcher. The passion with which the elderly members in Kumawu guarded the biodiversity resources and prevented unfriendly environmental activities, even by timber contractors who have been granted permits by the forestry commission in the area confirmed their full dedication to nature conservation.

Most of the respondents interviewed mentioned that environmentally degrading activities such as bad farming practices, throwing of refuse into river bodies and indiscriminate felling down of trees attract spiritual sanctions from the ancestors. This is largely due to the fact that the ancestors are advocates for the conservation and sustainability of biodiversity as deduced from the responses of the participants of the study. The elderly members of the society opined that «the vigilante ancestors who are interested in the successes and development of societies would punish anyone who abuses the biodiversity resources in the environment». The traditional authorities who occupy the seat of the ancestors tread their steps. They even make public their intentions when they are offering prayers or performing libation. They said «In our prayers and offerings to the ancestors, we consistently ask the ancestors to invoke their curses on anyone who doesn't want the society to progress and thereby engage in environmentally degrading activities». The researcher observed at firsthand, the performance of such libation ritual where death, sicknesses, and poverty were some of the curses invoked on those who disrupted the progress of society via bad practices like nature conservation. The full glare of such performance by the entire members of the community instills fear and discipline not to engage in any foul activity that would harm the environment and put the society in great peril. The researcher noticed in the comments of some elderly respondents who were influenced by Western education and religion that they did not share or have denounced the belief that they have in the existence of the 
ancestors. For instance, three elders in this category revealed to the researcher that "The ancestors are dead and gone and they do not exert any influence in the society. I think that the belief was established to instill fear in people not to abuse the environment so as not to incur the wrath and punishment of the ancestors. This fear, though not true, indirectly regulated the attitudes of people towards leading a green life». Their view reveals that indeed the waning of the belief in ancestors is as a result of the excessive impacts of western education and religion especially Christianity in the lives of Ghanaians as admitted by Boamah (2015) and Adom (2016a). However, the elderly in the society who do not share the belief in ancestors still respect and acknowledge the powerful roles of the belief in ancestors in conserving biodiversity and protecting the environment.

The majority of the youth does not believe in the existence of the ancestors. One elderly respondent explained the reason as "today's generation view our times and our belief in ancestors as the period of darkness and confiscation of knowledge (bagyimimmere). As such, they do not express any fear or whatsoever in the punishing power of the ancestors». Thus, they reason that in this modern age of enlightenment, there is no need for any superstitious fear about the reprimanding powers of the ancestors. Other respondents attributed it to the influx of Christianity and foreign culture. One elderly respondent said "Most of the youth feel that the blood of Jesus has covered everything. Thus, to them, the ancestors do not have any powers to inflict any pain or punishment to anyone, even the defaulters of biodiversity». Some of the youth is carelessly blinded by foreign culture and practices, viewing the belief in ancestors as foolishness and uncivilised. They view the punishment believed to issue from the ancestors as mere folk tales and do not take it seriously. The interviews with the few youth who shared the belief in ancestors revealed that these youth were previewed to the cultural knowledge of ancestors from close relatives who were well versed in the cultural traditions of the people. For instance, one youngster whose grandfather was the Gyaasehene (Sub-chief) of Kumawu told the researcher that "My father always ceases every opportunity he gets with the family to instruct us on the cultural traditions and beliefs handed down to them by their forebears. He narrates vividly, events that clearly showcase the influence of the powers and the assistance of the ancestors in their every- day life activities. They are so real and true such that one cannot dissuade the entire belief in ancestors as a mirage. The ancestors are there and their powers are real». This indicates that cultural education has a great force in shaping the beliefs and values of the youth in societies. Thus, if society is grieved that the youth are constantly leaving behind their cultural values and beliefs that play quintessential roles in development, such as nature conservation, there would be the need to intensify cultural education of the youth. Using informal settings such as the communal meetings as well as formal settings such as via educational institutions and the social media, the youth would be well instructed and knowledgeable in the cultural beliefs and values of society which advocates for nature conservation.

The interviews revealed that the experienced conservationists' work exposed them to the belief in ancestors. The researcher was shown specific spots in the Bomfobiri wildlife sanctuary where sacrifices are offered to the ancestors on every Thursday, which is a taboo day. The punishment imposed on stubborn project officers, some of which the conservationists have been eyewitnessed have instilled reverential fear in them not to offend the ancestors in any way or break their taboos and orders. The less experienced conservationists who have been posted directly from the universities did not hold a strong belief in the existence and/or the power of the ancestors. The traditional sanctions that are mostly spiritual from the ancestors are judged by the respondents as better than the modern environmental legislation that requires summoning at the law courts. One of the elders in the traditional court told the researcher that «The punishments from nananom (ancestors) are instantaneous and highly feared by community members». This regulates and maintains the upkeep of their orders and observance of their taboos. In addition, an abuse of rest days and fallow periods for the ancestors (Nnabone-bad days) attract the anger of the ancestors. The ancestors are believed to be holding their meetings and as such must not be disturbed. On the traditional calendar, there are nine sacred days (Awukudae), Tuesdays (Taboo day), and Sundays (Taboo day for the River Anokosu). The taboo day in the Bomfobiri wildlife sanctuary is on Thursday. The closed season when no hunting activities are to be carried out is from 1st August to 1st December every year. These rest days are to be kept by every member of the community to please the ancestors. 
An elderly woman narrated the ordeal she went through when she went to farm out of ignorance on a taboo day when she settled at Kumawu. She said "When I was weeding in my farm, I heard strange noises and couldn't trace the source. Suddenly, I saw numerous small snakes coming from underneath the earth where she was weeding. I left all my things behind and run to the house. After ten minutes, I experienced serious bodily pains that lasted for six months through the pacification rites performed by the traditional priest». Such stories are numerous and their narrations at communal gatherings instill fear in the people not to breach the taboos imposed by the Traditional Council. The huge impacts of the belief in ancestors and the reverential fear of displeasing them as well as the ultimate goal of pleasing them have aided in the conservation and sustainability of the biodiversity resources in Kumawu. These findings agrees with the observations made by Taringa (2006) that the fear of offending the ancestors restrains many local communities from cutting down trees dedicated to them.

Belief in Spirits/Deities, Animism and Sorcery and Witchcraft

The residents in Kumawu believe that all organisms in the environment have a deity or spirit inherent in them. Thus, it shows their belief in spirits and animism. Owing to this, it affects how the natural resources in the environment are treated and used. For instance, the numerous river bodies in the communities are believed to be the spirits that helped in the formation of the Kumawu town. As such, environmentally friendly activities are allowed to take place. Also, numerous taboos are to be observed in all the water bodies. For example, the researcher was informed that the River Anakosu and the River Abenasuo are not to be defiled in any way. The Gyaasehene said «The forest vegetation around the river is not supposed to be cut or encroached. Also, Sundays are the taboo day for the River Anakosu while Tuesdays are the taboo day for the River Abenasuo. During these days, no one is supposed to fetch from the river bodies. However, community members meet on such days to clear the path leading to the river bodies, pruning of tree branches that blurs vision to the river while removing all forms of debris in and around them». Other taboos included preventing residents from throwing anything into the river, sending and fetching water with silver buckets, having sexual intercourse in and around the river, women in their menstruation period are not supposed to fetch from the river bodies and fishing in the river using chemicals.

These taboos noticed by the researcher coincide with the taboos Boamah (2015) noted about the River Pra among the Akans of Ghana. Breaching these taboos is believed to incur the anger and spiritual powers of the river deities as well as monetary sanctions from the Kumawu traditional council. The researcher observed that marsh yam with cooked eggs was offered to the river deity as food every day. An elderly woman narrated a true life experience of seeing numerous dwarfs dancing in the River Abenasuo, which had turned muddy to the drum tunes she heard but did not see the drummers on a taboo day. She did not know, since she was a new resident in Kumawu. Another elderly respondent said to the researcher "Some three men stubbornly went to cut some of the palm trees around the Kwantempong River to be used by them for alcoholic beverage though it is tabooed. The deity in the river materialised himself into a breed of bees and attached them. They all fell sick for months as a result of the stubbornness». All these true life accounts confirm the belief of the residents that spirits reside in the natural resources in the environment. Owing to this, bad practices that defile the environment are not engaged in by the people. There were instances where the river deity materialises into other forms to punish abuses of their taboos.

The residents also believe that the wicked spirit known as Sasabonsam resides in the thick forest regions of Kumawu. He is believed to kill and hunt down anyone who enter the threshold on taboo days and also defile the forests. There was a narration of someone who went blind after his encounter with the Sasabonsam spirit on a taboo day. Therefore, residents would not dare enter the thick forests on taboo days, neither do they engage in unfriendly environmental activities. One elderly respondent shared his bad experience of meeting Sasabonsam on his way to the thick forest to hunt on a taboo day out of ignorance. He described him as having snakes dreadlocks, with feathers all over his body, having a strong pungent scent. He reprimanded and warned him not to come to the place again on a taboo day. He said Sasabonsam spared his life because he was ignorant of the taboo restriction. Thus, he has a strong belief in the existence of Sasabonsam who maintains sanity in the forests, ensuring that the plant species are not wantonly taken or destroyed. 
The researcher noticed that the mountains are viewed by the Kumawu residents as containing spirits. This observation concurs with the view of Little Bear (2000) who postulated that due to the belief that things in nature are animate and have spirits, they are treated by many who hold such beliefs as their relatives or deities who need to be respected and conserved. The mountains, rocks and water bodies in the Bomfobiri waterfalls (Fig. 4) are said to be gods who fought sometimes during disagreements. Sometimes, as a result of at loggerheads between the mountain spirits, they set barricades. The elders narrated what caused the raising of a small mountain between the two river bodies Owam and Ninai. Oral tradition told by the elders says that the River Ninai had relations with the daughter of Owam which he detested. As a result, a spirited small mountain was set between them. Particular plant species like Ahomakyem (Rourea solanderi Baker), Betene (Elaeis guineensis) and Odum (Milicia excelsa) are not to be cut. Spirits are believed to reside in such tree species. Special rites are performed to appease the spirit in the tree before it is cut. This agrees with the view of Eshun (2011) who mentioned that similar rites are performed by some ethnic societies before some plant species like Betene (Elaeis guineensis), Osese (Funtumia sp.), Odum (Milicia excelsa), and Mahogany (Khaya ivorensis A. Chev.) are cut. This clearly shows the great impact of the belief of Ghanaians in spirits inherent in some natural resources in the environment.

The researcher noticed that palm leaves were hung at the entrances of most of the houses in the community, especially the traditional palaces of the chiefs as well as the elders in the traditional council. These leaves are believed to ward evil spirits, witches and sorcerers. Again, the homesteads of the residential sites, as observed by the researcher, was rich in some indigenous plant species like $\mathrm{Nu}-$ futene (Kigelia africana) and Ajura (Philenoptera cyanescens (Schum. \& Thonn.) Roberty), plants that are believed to attract good spirits while repelling any vile spirits. This finding agrees with the notification of Gruca et al. (2014) who affirmed that the palm tree (Elaeis guineensis) has power to drive away bad spirits. This indicates the high belief in sorcery and witchcraft amongst the people and as such aiding in the conservation and richness of these particular indigenous flora species.

\section{Philosophical, Scientific and Conservation} Ethos of Kumawu Cosmological Belief Systems

A rigorous analysis of the cosmological belief systems of the residents in Kumawu shows that they are not just religiously inclined, but they have philosophical underwriting of science and conservation of nature's resources.
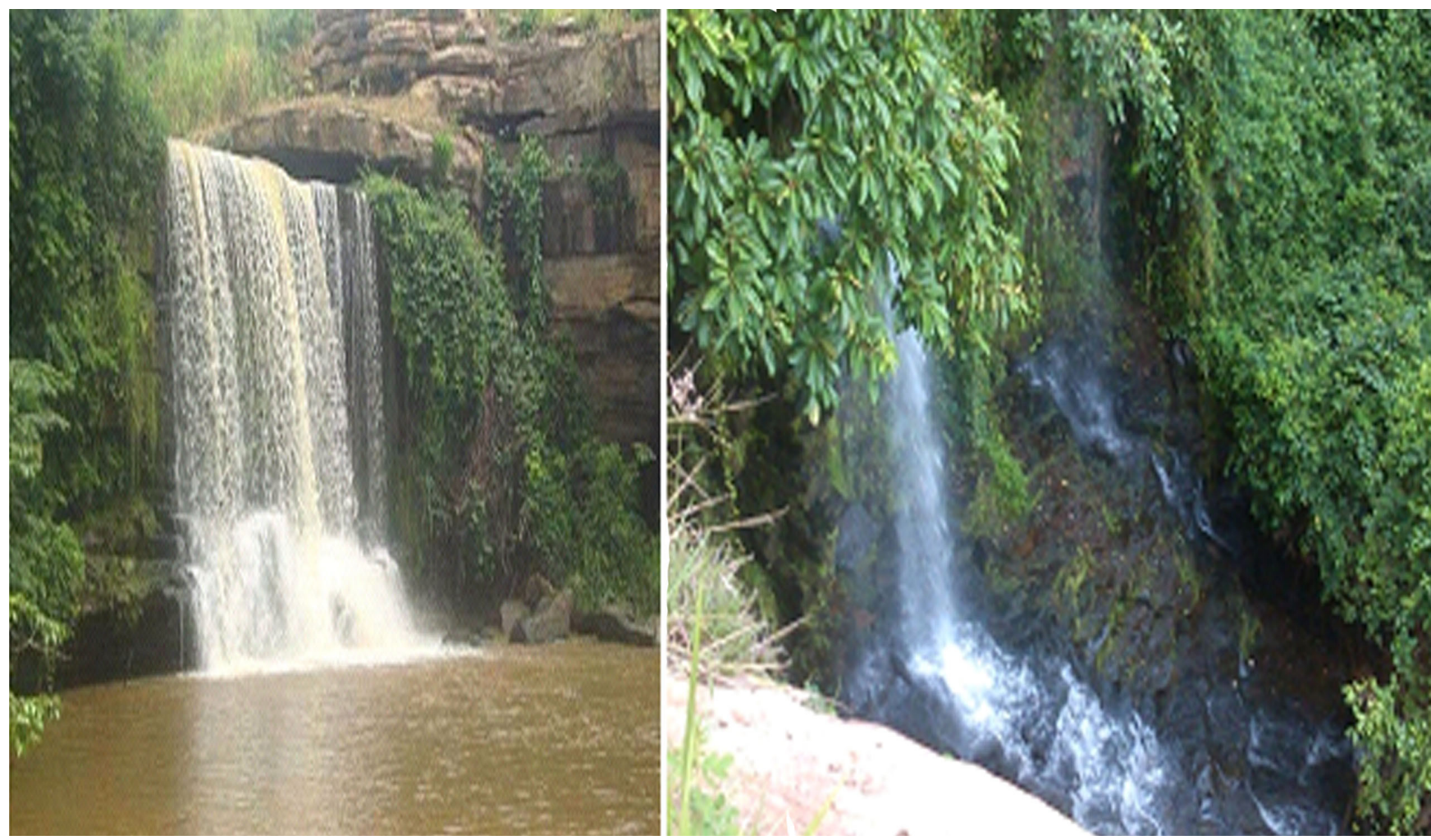

Fig. 4. Bomfobiri Waterfalls, Kumawu. 


\section{Harvesting Restraints}

The cosmological belief systems help in restraining uncensored harvesting practices. The belief in the Supreme Deity, ancestors and the spirits that perpetuate that the divine being hates individuals who greedily take the biodiversity in nature with no sustainability in mind. Thus, to win their favour and approval, residents do well to sustainable use the resources in nature. This indirectly aids in restraining the rates of harvesting the biodiversity resources. Moreover, the establishment of the taboo systems such as the taboo days reduces the harvesting pressure of the aquatic species in the river bodies, the cutting down of trees in the forests and the hunting of animals. For instance, Tuesday and Sunday are considered as taboo days for the River Abenasuo and the River Anakosu respectively. The Bomfobiri wildlife sanctuary and waterfalls are not supposed to be entered on Thursdays. Aside from these taboo days, there are nine sacred days known as Awukudae and Akwasidae where no one is supposed to engage in all forms of agricultural and hunting activities. These rest days (nnabone) indirectly assist in mitigating prolonged harvesting activities on the biodiversity in the Kumawu and Ghana as a whole.

\section{Protecting of Resource Species}

Among the residents in Kumawu, there are particular plant species, animal species and water bodies that are not supposed to be used but rather conserved. For instance, because of the belief that some plant species have strong spirits or deities residing in them, they are not abused or destroyed. This has ensured the conservation of some of these species that are endangered and rare in other regions of the world. Due to the protective spirits in flora species like Ahomakyem (Rourea solanderi), Betene (Elaeis guineensis) and Odum (Milicia excelsa), they are very abundant especially in the homesteads of residents in Kumawu. Also, the fishes and all aquatic species in rivers like Anakosu and Abenasuo are not supposed to be taken until the annual harvesting session begins. This has richly conserved the aquatic species in the rivers. In addition, the forest vegetation bank about ten yards supposed to be left around river bodies for fear of not being punished by the river deities has its own merits. For instance, the vegetation bank serves as a shade that prevents possible evaporation of the river bodies, always ensuring that its volume is always maintained or increased. It ensures the coolness of the water, making it potable for consumption. The taboos that prevent bad practices like using poisonous chemicals for fishing, throwing of refuse, the use of silver bowls and barriers for fetching water and others prevents the water bodies from possible pollution that would have made their consumption as well as the consumable aquatic species unhealthy. The ban on the hunting of specific fauna species regulated via the taboo system such as Roan Antelope (Hippotragus equinus É. Geoffroy Saint-Hilaire, 1803), Bongo (Tragelaphus euryceros Ogilbyi, 1837), Aardvark (Crycteropus afer Pallas, 1766), Manatee (Trichechus senegalensis Link, 1795) and many others have aided in their conservation in the Protected Area. This has greatly helped the Wildlife Corridor systems because hunters in the area do not kill such species and this allows them to enter the trail to the Bomfobiri Wildlife Sanctuary. These endangered species, alerted by the park officers in the Bomfobiri wildlife sanctuary have been safely kept as a result of taboos. Heeding to the taboos against their harvest is largely seen as a respect to the ancestors and spirits.

\section{Regulating the Onset or Duration of Harvests}

The rest days and fallow periods regulate the time span allowed for the harvesting of particular biodiversity species in the jurisdiction. For instance, it is a taboo in the Kumawu vicinity to engage in hunting from the first day of August to the first of December for all species with the exception of the very abundant herbivores. The closed season regulates the timing of resource harvests, including the wildlife and aquatic species in the river bodies. This is scientifically beneficial in ensuring the sustainability of these biodiversity resources in the environment. Interestingly, the taboo fallow period coincides with the period most of the animals get pregnant and/or nurse their young ones while the fishes in the rivers usually lay their eggs within this period. Thus, preventing harvesting in this period promotes the procreation and eventual maximisation of the amount of the biodiversity resources. The people have the belief that the ancestors are busy in the forests engaging in spiritual activities and need not be disturbed. Therefore, due to the deep reverence and fear for the irrevocable punishment from the ancestors, the people maintain the closed seasons every year. The park officers and the traditional authorities have also instituted measures to severely punish all those who do not respect the arrangements of the ancestors. They are sanctioned aside from the spiritual punishments from the ancestors. The traditional authorities and the park officers disclosed to the researcher that they record very few incidences of culprits breaking the taboo. These culprits are mostly strangers who are ignorant of the taboo systems to be observed. 
Avoidance of Harmful Habitat Modification

The Bomfobiri waterfalls and its forest threshold are considered as sacred by the people and are seen as the habitats of their early ancestors who established the town. An oral tradition has it that the site was exactly the spot where the first generation of their ancestors perished after they were beaten by bees said to be the metamorphosed Dente deity from Krachi in the Ashanti region. It is said that the deity punished them by death as a result of their refusal to show hospitality towards him. Therefore, the place is believed to be the perpetual dwellingplace of their ancestors and as such must not be modified, encroached and/or destroyed. As a result of assigning the habitat as the abode of the ancestors, it will be gross disrespect and an unforgivable act for the powerful ancestors. Moreover, residents believe that their family buildings with homesteads harbour the spirits of their family ancestors and as such must not be destroyed or modified. They believe that if the sites or habitats are modified, they may lose touch with their ancestors and that would be disastrous for their spiritual protection. This indicates that the cosmological belief systems indirectly assist in the conservation of very rich, rare and highly diversified biodiversity species.

\section{Patch-Switching to Maximise Overall Return}

The view of residents in Kumawu as shared by most Ghanaians is that it will be cruelty and disrespect to overly till or farm on the same land perpetually. Issuing from the belief that the earth (Asase Yaa) is a mother who must be shown reverence, the residents desist from degrading one patch of land continuously for agricultural activities. It would be tantamount to being ungrateful toward the gracious land that provided for you. Thus, some of the residents who were farmers told the researcher that «The land that is tilted and used for agricultural purposes must be allowed to rest. Taking it away from her would be a gross sin which would not go unpunished by the owner of all the land mass, Mother Earth (Asase Yaa)». Therefore, the cultivated land is given enough time to rest while another arable piece of land is used for farming. Ecologically, the belief in animism that requires reverence for things in nature, such as the landmass because they are habited by spirits has helped in maximising the yield or overall return on the harvest. Scientifically, when a land is overly harvested, the nutrients in the soil depreciate and as such results in reduced yield. Therefore, the belief of allowing the earth to rest as if it were human correlates with the scientific agricultural practice of shifting cultivation. This practice of patchswitching ensures sustained farming and conservation of biodiversity.

A Synergy of Traditional Cosmology of Kumawu with the Scientific Conservation Practices in the Bomfobiri Wildlife Sanctuary

The traditional cosmology of the people of Kumawu can be effectively synergised with the scientific conservation practices to enhance nature conservation in the Bomfobiri Protected Area. The suggested forms of applying the traditional cosmology and scientific nature conservation strategy have been stated below.

Re-Introduction of New and Threatened Species in the Protected Area

The park officer in the Bomfobiri Wildlife Sanctuary disclosed to the researcher that some animal species are getting threatened and their numbers are fast reducing. Therefore, they have instituted wildlife corridors to re-introduce these species back into the Protected Area. Many of the threatened species in the Protected Area are in the off reserve areas where licensed hunters are allowed to hunt them. There has been a ban on the hunting of these species but the situation is getting out of hand. Therefore, the conservationists should liaise with the traditional authorities to deify these species. Because of the huge respect and reverence the Kumawu residents have for the ancestors, they would leave these animal species untouched to move freely through the created wildlife corridors to reintroduce them into the Wildlife Sanctuary. This would aid in avoiding the possible extinction of these animal species in the sanctuary.

\section{Boosting Species Richness while Ensuring} Sustainability in the Protected Area

The taboo days must also be respected by the conservationists and must be woven into their plans and programmes. Scientifically, nature is to be allowed to perform its healing processes to restore its strength to better perform its ecological services. They must not be seen as a waste of time and ecotourism revenue as some of the conservationists in the Bomfobiri Wildlife Sanctuary mentioned. They must be wholly supported by the conservationists because the practice is a viable conservation strategy. The taboos observed by the people of Kumawu are strong because their enforcement by the $\mathrm{Ku}$ mawu Traditional Council has made the percentage 
of those observing them are very high. This high rate in the application of the taboos, Fershtman et al. (2011) strongly opine, makes its application in regulating the behaviours of people very successful. Thus, all unfriendly environmental practices can be tabooed within the traditional cosmology of the people for smooth conservation of biodiversity.

Environmental Education on Sound Environmental Practices for Conservation of Natural Resources in the Protected Area

Due to the influx of foreign culture, religion and education, many of the Kumawu youth are losing touch of their traditional cosmology. Thus, the Kumawu Traditional Council has used the communal meeting days to carry out such cultural education. The conservationists working in the Bomfobiri Wildlife Sanctuary must help boost such traditional cosmological education that bolsters nature conservation. They can use the platform to abreast the community members of the scientific conservation practices that are akin to the traditional cosmology of the people. For instance, the scientific conservation practice of closed seasons from where the animals in the reserve engage in mating and procreation coincides with the time when the ancestors are not to be disturbed as Boateng (1998) purported.

Plantation of Seedlings of Tree Species to Restore Degraded Portions of Protected Area

The traditional cosmology of the residents of Kumawu postulates that when a life is lost, a new life must begin to replace the lost life. In the same analogy, when a plant is cut, there is the need to replace it by a new plantation. This is the will of the ancestors which is promoted through traditional cosmology. As such, the conservationists must assist the Kumawu Traditional Council to espouse and promote this traditional ideology that heightens the afforestation strategy in the scientific strategies to replenish degraded areas of the Protected Area.

Promotion of Communal Labour for Environmental Sanitation

The traditional cosmology of Kumawu emphasises cleanliness of the environment and one's surroundings. It is born out of their belief that the ancestors are constant policing agents in the community. They abhor unclean surroundings and bad environmental practices like throwing of refuse in gutters, defecating into rivers and nearby water bodies. These situations are prevalent among some na- tive residents and especially, the non-native residents of Kumawu. They throw all kinds of debris into the water bodies that enjoin the Bomfobiri waterfalls which serve as the main water source for the biological resources in the Protected Area. Therefore, the weekly communal labour organised with the view of pleasing the ancestors must be encouraged and supported by the conservationists in the Bomfobiri Wildlife Sanctuary. They can provide publicity for such activities in the Kumawu region while providing the needed logistics for this weekly communal labour. This arrangement in the traditional cosmology can complement the scientific environmental cleansing activities propagated by the conservationists at the Bomfobiri Wildlife Sanctuary.

\section{Conclusions}

The main driving force for the research was to highlight the significant roles that cosmological belief systems play in nature conservation using the case of the residents in Kumawu in the Ashanti region of Ghana. It was also aimed at providing substantial evidence to debunk the wrong assertions and demeaning remarks made by some scholars and nature conservation planners that the indigenous cosmological belief systems of local communities such as Kumawu are not worthwhile as far as conservation of biodiversity is concerned. Using Smith \& Wishnie's (2000) analytical procedure for assessing the conservation values of traditional knowledge systems, the researcher has accentuated with enough evidence, the quintessential roles that cosmological belief systems play in nature conservation. The revelations from the study showed that the cosmological beliefs in the Supreme Deity, ancestors, spirits, animism as well as sorcery and witchcraft have instilled reverential fear in people not to abuse the biodiversity resources in nature that are seen as spirited and face the spiritual and physical repercussions from the spirits. The sacrosanct treatment of some habitats, biodiversity and numerous taboos restraining bad environmental practices have all contributed indirectly to the prevention of resource exploitation, avoidance of habitat destruction, and restrained excessive harvesting practices. Again, the research has revealed that these cosmological belief systems actually have philosophical underwriting of science and correlates in many instances to the dictates of the conventional scientific models of conservation. The study has accentuated how traditional cosmology can be synergised with the scientific conservation practices in Protected Areas in Ghana using the case of the Bomfobiri Wildlife Sanctuary. 
Moreover, as it has been illustrated in the study, monitoring the behavioural patterns of residents is one of the surest means of curbing the decline in biodiversity resources and the mitigation as well as the possible cessation of biodiversity depletion. These cosmological belief systems established by the predecessors in the genesis of life were ultimately aimed at helping in developing good traits in individuals to curtail the uncensored use of the biodiversity resources in nature. Thus, it would not be academic to dissuade the page of cosmological belief systems as irrelevant. In our modern societies where problems to social phenomena cannot be arrested using a truncated approach, there is the need to consider rigorously, the potentials of other forms of knowledge, such as cosmological belief systems and evaluate how they can be formulated into conservation strategies to complement the scientific models of conservation that is widely implemented. Indeed, the researcher agrees with the assertion of Mapira \& Mazambara (2013) that humans cannot preserve the biodiversity resources in nature without taking into account the human cultures and beliefs that have been the sole agents for their protection since the dawn of time. Therefore, policy makers and developers of nature conservation strategies and policies must look into the cosmological belief systems of people and weave them into traditional biodiversity strategies. Ultimately, it would assist in providing a new traditional conservation strategy for biodiversity that would serve as a viable complement to the existing scientific conservation strategies to form a synergistic, pluralistic and multi-faceted approach to give hope for the current grim future of biodiversity. Therefore, these recommendations have been put forward to ensure the smooth implementation of the traditional cosmology of the residents in the Kumawu Traditional Area to aid in the conservation of the natural resources in the Bomfobiri Wildlife Sanctuary:

1. The taboo days and closed seasons where no entry is allowed into the Wildlife Sanctuary or its buffer zones must be strengthened and encouraged by the conservationists with collaboration with the Kumawu Traditional Council. These periods when all forms of hunting or agricultural activities are banned promotes the conservation of nature's resources. For instance, the closed season from 1st August to 1st December every year helps the biological species to procreate and increase in their numbers. Moreover, it assists nature ample time to perform its ecological and recovering processes while restraining the harvesting of nature's resources for sustainable supply to the present and future generations. In their sensitisation programs, the conservationists must highlight the ecological importance of observing the taboo days and closed seasons to the people and explain why their intelligent ancestors who cared for them and the unborn generations made the arrangements. Sensitisation of the taboos regarding the abuse of river bodies and the forests must be equally promoted at societal gatherings where environmental education is carried out by the park officers engaging the Traditional Council and residents.

2. Provisions of sustainable alternative sources of employment in the Kumawu Traditional Area are keen to the prevention of the gradual entering into the territorial boundaries of the Wildlife Sanctuary. The Forestry Commission of Ghana must liaise with public and private agencies to raise funds for such course. Moreover, the Government of Ghana through the Ministry of Lands and Natural Resources must work at developing and upgrading of the eco-tourism potentials of the Sanctuary to yield more employment avenues for the local people of Kumawu. Also, the Forestry Commission must assist the local people, especially the farmers with the relevant skills expertise to set up small scale enterprises in Non-Forestry Timber Products like bee making, mushroom plantation, snail production etc. Financial institutions must be engaged by the Forestry Commission of Ghana to offer soft loans with less interest rates to the local farmers to be used as capital. This would prevent the poor local people from engaging in and/or condoning bad environmentally unfriendly activities in the Bomfobiri Wildlife Sanctuary and its buffer zones.

3 . The Forestry Commission and the Park managers must intensify the propagation of the ideals of stewardship and accountability in their environmental education campaigns which is seen in their traditional cosmology to appeal to the consciences of the local people. During such environmental education sessions, the deep respect for the ancestors and the Supreme Deity held by the local people must be espoused and the repercussions from them to culprits of environmental malfeasance. This should be done inter alia the scientific education processes. This would promote the conservation and sustainable use of the nature's resources in the area so as not to encroach on the threshold of the Wildlife Sanctuary.

4. The Forestry Commission should supply material incentives to the Traditional Council of Kumawu by heightening the arrangements for equitable sharing of the proceeds from the Wildlife Sanctuary through the ecotourism revenue. This 
would motivate them in ensuring the full implementation of the traditional cosmological beliefs to back the scientifically inclined conservation procedures in the Protected Area. The Traditional Council must be allowed by legislation and bylaws of the Forestry Commission and the Government of Ghana to dispense punishments to persons who wantonly destroy the natural resources in the area. This is due to the fact that they are more stringent, resilient and are feared by the people. The traditional system of punishment was and is still effective in preventing resource exploitation. They are also swift and communal fashion. Thus, the park officers must implement them in conjunction with their scientific conservation strategies.

5. During the Papa Festival celebrated by the people of Kumawu, the park officers must liaise with the Traditional Council to draw the line of activities for the programme. They must use the event as a platform for communal environmental education. The local people can be engaged in tree plantation activities in the degraded areas of the Bomfobiri Wildlife Sanctuary as part of the festival programme. The traditional forms of education, such as the use of proverbs, folklores and storytelling which is popular among the people must be tactfully used as mediums for environmental education. This can be done via effective and mutual cooperation between the Park officers and the Kumawu Traditional Council.

\section{References}

Population and Housing Census. 2010. District Analytical Report. Sekyere Afram District. Ghana Statistical Service, 2014. $82 \mathrm{p}$.

Abrams N.E., Primack J.R. 2001. Cosmology and 21 ${ }^{\text {st }}$-Century Culture. Science 293(5536): 1769-1770. DOI: 10.1126/science. 1063090

Adom D. 2014. General Knowledge in Art for Senior High Schools. Kumasi: Adom Series Publications Limited

Adom D. 2016a. Asante Indigenous Knowledge Systems: Repositories of Conservation Ethics for Ghana's Biodiversity. In: Sub-Sahara Indigenous Knowledge and New Discoveries in the New Millennium: Interdisciplinary Approach. Vol. 7(2). Sokoto, Nigeria: Uthman Danfodio University. P. 8-36.

Adom D. 2016b. Inclusion of Local People and Their Cultural Practices in Biodiversity Conservation: Lessons from Successful Nations. American Journal of Environmental Protection 4(3): 67-78. DOI: 10.12691/env-4-3-2

Adom D., Kquofi S., Asante E.A. 2016. The High Impacts of Asante Indigenous Knowledge In Nature Conservation Issues In Ghana: The Case Of The Abono And Es- sumeja Townships In Ashanti Region. British Journal of Environmental Sciences 4(3): 63-78.

Adu-Gyamfi M. 2011. Indigenous Beliefs and Practices in Ecosystem Conservation: Response of the Church. Scriptura 107: 145-155.

Aikenhead G., Masakata O. 2007. Indigenous Knowledge and Science Revisited. Cultural Studies of Science Education 2: 539-620. DOI: 10.1007/s11422-007-9067-8

Amponsah K. 1977. Topics on West African Traditional Religion, Vol. 1. Accra: Adwinasa Publications Limited.

Awuah-Nyamekye S. 2013. Managing the Environmental Crisis in Ghana: The Role of African Traditional Religion and Culture-A Case Study of Berekum Traditional Area. Doctoral Thesis. Leeds, UK: University of Leeds. 249 p.

Battiste M. 2002. Indigenous Knowledge and Pedagogy in First Nations Education. A Literature Review with Recommendations. Ottawa, Canada: National Working Group on Education \& Indian and Northern Affairs. 33 p.

Bergmann S., Gerten D. (Eds.). 2010. Religion and Dangerous Environmental Change: Transdisciplinary Perspectives on the Ethics of Climate and Sustainability. Berlin: LIT Verlag. 256 p.

Boamah A. D. 2015. Akan Indigenous Religio-Cultural Beliefs and Environmental Preservation: The Role of Taboos. Master's Thesis. Canada: Queens University. 59 p.

Boateng B.A. 1998. Traditional conservation practices: Ghana's Example. Research Review 14(1): 42-51

Bowie F. 2006. The Anthropology of Religion: An Introduction. Oxford: Wiley-Blackwell. 344 p.

Chalk J.R. 2006. Genesis 1-11 and the African Worldview: Conflict or Conformity? PhD Thesis. Pretoria: University of South Africa. 278 p.

Cosmology Blog. 2008. Cosmology and Anthropology: Toward a Definition. Available from: http://timeo-habla. blogspot.ru/2008/09/cosmology-and-anthropologytowards.html. Retrieved on 26.11.2017.

Creswell J.W. 2009. Research Design: Qualitative, Quantitative, and Mixed Methods Approaches. $3^{\text {rd }}$ ed. USA: SAGE Publications, Inc. 296 p.

Cunningham S. 1985. Cunningham's Encyclopedia of Magical Herbs. London: Llewellyn Publications. 318 p.

Diawuo F., Issifu A.K. 2015. Exploring the African Traditional Belief Systems in Natural Resource Conservation and Management in Ghana. Journal of Pan African Studies 8(9): 115-131.

Ens E., Scott M.L., Rangers Y.M., Moritz C., Pirzl R. 2016. Putting Indigenous Conservation Policy into Practice Delivers Biodiversity and Cultural Benefits. Biodiversity and Conservation 25(14): 2889-2906. DOI 10.1007/s 10531-016-1207-6

Eshun E.K. 2011. Religion and Nature in Akan Culture: A Case Study of Okyeman Environment Foundation. Master's Thesis. Ontario, Canada: Queens University Kingston. 56 p.

Fraenkel J., Wallen N., Hyun H. 2012. How to Design and Evaluate Research in Education ( ${ }^{\text {th }}$ ed.). New York: McGraw-Hill Education. 704 p. 
Fershtman C., Gneezy U., Hoffman M. 2011. Taboos and Identity: Considering the Unthinkable. American Economic Journal: Microeconomics 3(2): 139-164.

Gamble F. 2016. What is Worldview and Why is it Important? Available from: http://www.thrivemovement.com/ what-worldview-and-why-it-important. Retrieved on 05.08.2016.

Gbolonyo J.S.K. 2009. Indigenous Knowledge and Cultural Values in Ewe Musical Practice: Their Traditional Roles and Place in Modern Society. PhD Thesis. Pittsburgh, USA: University of Pittsburgh. 585 p.

Gifford R., Kormos C., McIntyre A. 2011. Behavioural Dimensions of Climate Change: Drivers, Responses, Barriers, and Interventions. Wiley Interdisciplinary Reviews: Climate Change 2(6): 801-827. DOI: 10.1002/wcc.143

G'Nece J. 2012. The Importance of Indigenous Knowledge and Good Governance to Ensuring Effective Public Participation in Environmental Impact Assessments. Maryland, USA: ISTF News. 19 p.

Grenier L. 1998. Working with Indigenous Knowledge: A Guide for Researchers. Ottawa: International Development Research Centre. 100 p.

Grim J.A. (Ed.). 2001. Indigenous Traditions and Ecology: The Interbeing of Cosmology and Community. Cambridge: Center for the Study of World Religions. $824 \mathrm{p}$.

Gruca M., van Andel T.R., Balslev H. 2014. Ritual Uses of Palms in Traditional Medicine in Sub-Saharan Africa: A Review. Journal of Ethnobiology and Ethnomedicine 10: 60. DOI: $10.1186 / 1746-4269-10-60$

Gyekye K. 1996. African Cultural Values: An Introduction. Accra: Sankofa Publishing Company. 194 p.

Golo B.W.K., Yaro J.A. 2013. Reclaiming Stewardship in Ghana: Religion and Climate Change. Nature and Culture 8(3): 282-300. DOI: 10.3167/nc.2013.080304

Hedlund-de Witt A. 2013. Worldviews and the Transformation to Sustainable Societies. PhD Thesis. Amsterdam: Vrije Universiteit Amsterdam. 364 p.

Infield M., Mugisha A. 2013. Culture, Values and Conservation: A Review of Perspectives, Policies and Practices. Cambridge, UK: Fauna and Flora International. 28 p.

Iyoro A.O., Ogungbo W.O. 2013. Management of Indigenous Knowledge as a Catalyst Towards Improved Information Accessibility to Local Communities: A Literature Review. Chinese Librarianship: An International Electronic Journal 35: URL: http:/www.iclc.us/cliej/cl3510.pdf

Kehinde O. 2013. African Religion and Environmental Dynamics. Journal of Studies in Social Sciences 4(2): 199-212.

Kumekpor K.B. 2002. Research Methods \& Techniques of Social Research. Ghana: SonLife Printing Press and Services. 304 p.

Leach E. 1982. Social Anthropology. Oxford, UK: Oxford University Press. 254 p.

Leedy P.D., Ormrod J.E. 2010. Practical Research: Planning and Design ( $9^{\text {th }}$ ed.). Upper Saddle River, New Jersey: Pearson Education, Inc. 336 p.

Little Bear L. 2000. Jagged worldviews collide. In: M. Battiste (Ed.): Reclaiming indigenous voice and vision. Vancouver, Canada: UBC Press. P. 77-85.
Mapira J., Mazambara P. 2013. Indigenous Knowledge Systems and their implications for Sustainable Development in Zimbabwe. Journal of Sustainable Development in Africa 15(5): 90-106.

Milton K. 1996. Environmentalism and Culture Theory: Exploring the Role of Anthropology in Environmental Discourse. London: Routledge Taylor and Francis Group. 276 p.

Msuya T.S., Kideghesho J.R. 2009. The Role of Traditional Management Practices in Enhancing Sustainable Use and Conservation of Medicinal plants in West Usambara Mountains, Tanzania. Tropical Conservation Science 2(1): 88-105. DOI: 10.1177/194008290900200109

Museka G., Madondo M.M. 2012. The Quest for a Relevant Environmental Pedagogy in the African Context: Insights form Unhu/Ubuntu Philosophy. Journal of Ecology and the Natural Environment 4(10): 258-265. DOI: 10.5897/JENE12.052

Myers M.D. (Ed.). 2008. Qualitative Research in Business and Management. London: SAGE Publications. 296 p.

Nachmias F.C., Nachmias D. 1992. Research Methods in Social Sciences. $4^{\text {th }}$ ed. New York : St. Martin's Press. 576 p.

NBSAP. 2015. National Biodiversity Strategy and Action Plan: Fifth National Report to the CBD 2015. Brasilia: Ministry of the Environment, Secretariat of Biodiversity and Forests, Center for Information and Documentation, Federal Republic of Brazil. 231 p.

Opoku K.A. 1978. West African Traditional Religion. Singapore: FEP International Private Ltd. 182 p.

Our Worldviews. 2016. Introduction. Available from: http:// schools.cbe.ab.ca/b690/Curriculum/socialstudies/ourworldview-8/ss_ourwvs8/Attachments/a_student_text/ SS8SB002.pdf. Retrieved on 26.11.2017.

Pope C., Ziebland S., Mays N. 2000. Analysing Qualitative Data. British Medical Journal 320(7227): 114-116.

Pretty J., Adams B., Berkes F., Ferriera de Athayde S., Dudley N., Hunn E., Maffi L., Milton K., Rapport D., Robbins P., Sterling E., Stoltin S., Tsing A., Vintinner E., Pilgrim S. 2009. The Intersections of Biological Diversity and Cultural Diversity: Toward Integration. Conservation and Society 7(2): 100-112. DOI: 10.4103/0972-4923.58642

Rattray R.S. 1916. Ashanti Proverbs: The Primitive Ethics of a Savage People. Oxford: The Clarendon Press. 190 p.

Reichel E. 2005. Cosmology. In: B. Taylor, J. Kaplan (Eds.): The Encyclopedia of Religion and Nature. London: Thoemmes Continuum. P. 420-425.

Reuter J. 2013. Values and Worldviews. In: J. Reuter (Ed.): Diagnosing and Engaging with Complex Environmental Problems. P. 62-64.

Rim-Rukeh A., Irerhievwie G., Agbozu I.E. 2013. Traditional Beliefs and Conservation of Natural Resources: Evidences From Selected Communities in Delta State, Nigeria. International Journal of Biodiversity and Conservation 5(7): 426-432. DOI: $10.5897 /$ IJBC2013.0576

Schlitz M.M., Vieten C., Miller E.M. 2010. Worldview Transformation and The Development of Social Consciousness. Journal of Consciousness Studies 17(78): 18-36. 
Schiffman L., Bednall D., O’Cass A., Palandino A., Ward S., Kanuk L. 2008. Consumer Behaviour (4th ed.). Frenchs Forest, Australia: Pearson Education. 664 p.

Shastri C.M., Bhat D.M., Nagaraja B.C., Murali K.S., Ravindranath N.H. 2002. Tree Species Diversity in a Village Ecosystem in Uttara Kannada District in Western Ghats, Karnataka. Current Science 82: 1080-1084.

Smith E.A., Wishnie M. 2000. Conservation and Subsistence in Small-Scale Societies. Annual Review of Anthropology 29: 493-524. DOI: 10.1146/annurev.anthro.29.1.493

Soini K., Dessein J. 2016. Culture-Sustainability Relation: Towards a Conceptual Framework. Sustainability 8(2): 167. DOI: $10.3390 / \mathrm{su} 8020167$

Taringa N. 2006. How Environmental is African Traditional Religion? Exchange 35(2): 191-214. DOI: $10.1163 / 157254306776525672$

Traditional Lifestyles and Biodiversity Use Regional Report. 2003. Composite report on the status and trends regarding the knowledge, innovations and practices of indigenous and local communities. Regional re- port: Africa. Prepared for the Secretariat of the Convention on Biological Diversity. Project number: 1248. UNEP-WCMC.

Uphoff N. 1992. Local Institutions and Participation for Sustainable Development. Washington D.C.: International Institute for Environment and Development. 16 p.

Van Asselt M.B.A., Rothmans J. 1996. Uncertainty in Perspective. Global Environmental Change 6(2): 121-157. DOI: 10.1016/0959-3780(96)00015-5

Vidal C. 2008. Wat is een wereldbeeld? In: H. Van Belle, J. van der Veken (Eds.): Nieuwheid Denken. De Wetenschappen En Het Creatieve Aspect Van De Werkelijkheid. Leuven: Acco. P. 71-85.

Wilder B.T., O’Meara C., Monti L., Nabhan G.P. 2016. The Importance of Indigenous Knowledge in Curbing the Loss of Language and Biodiversity. BioScience 66(6): 449-509. DOI: 10.1093/biosci/biw026

Yronwode C. 2002. Hoodoo Herb and Root Magic: A Materia Magica of African-American Conjure. 4th ed. California: Lucky Mojo Curio Company. 224 p.

\title{
ТРАДИЦИОННАЯ КОСМОЛОГИЯ И СОХРАНЕНИЕ ПРИРОДЫ В ЗАКАЗНИКЕ ДИКОЙ ПРИРОДЫ БОМФОБИРИ (ГАНА)
}

\author{
Д. Адом \\ Университет науки и технологии Кваме Нкрума, Гана \\ e-mail:adomdick@yahoo.com
}

\begin{abstract}
Системы космологических убеждений играют значительную роль в сохранении биоразнообразия жителей традиционной области Кумаву в Гане. К сожалению, они были несправедливо признаны как препятствие для научного прогресса. Это привело к тому, что их мнение слабо учитывалось в инициативах по сохранению природы в этой области. Таким образом, исследование было направлено на выявление природоохранного аспекта систем космологических убеждений, аргументируя, почему они должны использоваться в современных инициативах по сохранению природы. Феноменологическое исследование с использованием обсуждений в целевых группах, личные интервью и прямые наблюдения помогли собрать качественные данные, которые были тщательно проанализированы с помощью спирального подхода. Выводы показали, что системы космологических убеждений в значительной степени влияют на отношение жителей традиционной области Кумаву к сохранению природных ресурсов в заказнике дикой природы Бомфобири. В исследовании утверждается, что при планировании природоохранных мероприятий в Гане необходимо глубже проникать в системы космологических убеждений в этом районе и их следует обозначить как потенциальную традиционную стратегию сохранения биоразнообразия и рассматривать в качестве дополнения к традиционным научным моделям, чтобы противостоять угрозе сокращения биоразнообразия в заказнике дикой природы Бомфобири.
\end{abstract}

Ключевые слова: биоразнообразие, заказник дикой природы Бомфобири, основы поведения, природа, системы космологических убеждений, сохранение, традиционная область Кумаву 